\title{
Chapter 4 \\ Legal Status, Gender, and Economic Incorporation of Senegalese Migrants in France, Italy, and Spain
}

The economic integration of migrants is a major concern for policy makers, as is the legal status of immigrants in the labor market. While immigration-control legislation that confers residence and work authorization should theoretically mediate migrants' access to the labor force, the presence and economic activity of millions of undocumented migrants in different receiving countries indicates that irregular legal status is often not a barrier to work. Indeed, some research suggests that immigrants are able to find work precisely because of their irregular status, which removes most legal recourse against exploitation by unscrupulous employers (Portes 1978). Migrants are thus assumed to have economic motivations for their migration and to work in the destination economy regardless of their legal status.

This common perception of the link_-or lack thereof-between migrants' legal status and their economic incorporation fails to consider the role of gender. While post-war labor migration, both regular and irregular, to the U.S. and Western Europe was mostly male, flows of immigrants since the 1970s have seen an increasing share of women, many of whom entered through legal channels of family reunification (Kofman 1999). Although research has underlined the heterogeneity of these migrant women's legal and economic situations, family-reunification policies have been highly gendered and have largely consigned women to economic and administrative dependency on their male sponsors. In addition, countries award different configurations of authorizations to reunified family members, thus creating a variety of forms of dependency (González-Ferrer 2011b).

Despite possessing a form of regular legal status, then, migrant women may initially be less likely to work than their male counterparts. While this has provoked

\footnotetext{
The original version of this chapter was revised: Footnote was inserted in the chapter opening page. The correction to this chapter is available at https://doi.org/10.1007/978-3-030-12088-7_7

Portions of Chapter 4 were previously published as: Vickstrom, E. R., \& González-Ferrer, A. (2016). Legal status, gender, and labor market participation of Senegalese migrants in France, Italy, and Spain. The Annals of the American Academy of Political and Social Science, 666(1), 164-202. https://doi.org/10.1177/0002716216643555.
} 
concerns about the growing numbers of inactive and "unproductive" migrants in some countries (Constant and Zimmermann 2005), the initial gendered asymmetry of economic integration may obscure subsequent mobility among women into the labor market. The impact of legal status on migrants' economic integration thus seems to depend crucially on gendered channels created by immigration policies.

This chapter will draw on the literature on the gendering of immigration policies to examine the link between legal status and economic incorporation of Senegalese migrants in France, Italy, and Spain. It argues that the effect of legal status on Senegalese migrant's labor-market participation will vary differ for men and women because of gendered immigration policies. The chapter is organized as follows. The next section reviews the literature on gendered immigration policies and the creation of migrant women's economic and administrative dependency. The third section lays out the chapter's hypotheses. The fourth section reviews the data and presents the methods. The fifth section presents the results, and the sixth section discusses the findings and concludes.

\subsection{Gendered Channels of Migration: Family Reunification, Legal Status, and Dependency}

Research since the 1980s has increasingly focused on the exclusion of women from studies of the economic incorporation of migrants (Kofman 1999, 2004a). One of the main insights of this body of research is that immigration policies, while officially gender-neutral, have differential impacts on the mobility and subsequent economic integration of male and female migrants (Lesselier 2008). Men were the primary beneficiaries of labor-recruitment policies in both the US and Western Europe up through the 1960s and 1970s (Lesselier 2008; Mahler and Pessar 2006). Governments, especially those in Western Europe, severely restricted these legal channels of labor immigration after the mid-1970s but continued to allow migrants legally residing in destination countries to bring close family members under family reunification schemes.

Indeed, family reunification has become the main channel of legal entry to most Western European countries (Kofman 1999). In France, for example, $70 \%$ of entries in 2008 were for family reasons, and family reunification with long-term foreign residents make up between 90,000 and 150,000 entries per year since 2000 (Lesselier 2008). Research has shown, though, that family reunification is highly gendered: women, mostly spouses, make up the majority of reunified family members (Kofman 1999). Fully $80 \%$ of the aforementioned annual entries for family reunification in France were women (Lesselier 2008). While not all women are reunified spousesresearch has increasingly pointed to a growing "feminization" of autonomous migration (Kofman 2004b) - family reunification remains the dominant channel of entry for women into most destinations and structures their legal and economic incorporation. 


\subsubsection{Reunification and Gendered Economic and Administrative Dependency}

Research has shown that family reunification policies create economic and administrative dependency for women, and that these forms of dependency have implications for women's economic participation in destination-country labor markets (Boyd 1997; Lesselier 2008). Economic dependency among reunified spouses may arise from the legal requirements of demonstration of means of support by the sponsor. Family reunification policies often define male migrants as the primary breadwinners through the economic conditions imposed for reunification (Kofman 2004a; Mahler and Pessar 2006), creating economic dependency of women on their husband's income (Lesselier 2008). Reunified spouses may thus be less likely to work because of their sponsors' relatively high socioeconomic status (Toma 2012).

Economic dependency of reunified spouses may also arise because of legal barriers to their labor-market participation. Legislation may formally prevent women from accessing the labor market by imposing waiting periods on the ability of reunified spouses to apply for and receive work permits, as is the case in Italy and Spain (Kofman 1999). The separation of residence and work permits that is common in Europe thus means that the legal right to reunify is not always synonymous with the legal right of reunified spouses to enter the labor force (Boyd 1989). Indeed, research on the "admission category" of migrants has generally found that refugees and reunified family members have worse labor-market outcomes than those of economic migrants (Constant and Zimmermann 2005); these findings demonstrate the barriers that admissions policies impose rather than the motivations or unobserved characteristics of the admitted migrants (González-Ferrer 2011a). Reunified women who are excluded from the labor force as a result of legal waiting periods are thus dependent on their spouses for economic support, or they are forced to work illegally. Indeed, reunified women who have economic in addition to family motivations for migration may bypass the legal reunification channel because it is, in effect, no different from irregular channels of reunification in terms of accessing the labor market (González-Ferrer 2011a).

In addition to economic dependency as a result of family reunification, women are often subject to administrative dependency. Immigration legislation makes the possibility of reunification conditional on the sponsor's regular legal status (Lesselier 2008). Women wishing to rejoin their husbands legally are therefore dependent on his acquisition of regular legal status. In addition, the legal status of reunified spouses after arrival is dependent on the primary migrant's continued possession of regular legal status and the continuation of the marriage (Lesselier 2008). Women's geographic mobility is thus subject to dependency both in relation to the state and within the household (Kofman 2004b). These asymmetric power relations may reduce women's autonomy in making decisions about labor-market participation by tying them administratively to a husband's legal situation. This dependency can decrease women's bargaining power within the household, giving them less voice in their husbands' decisions in the allocation of their labor to either productive or reproductive efforts (Kofman 1999). In countries such as France where there is no 
waiting period for applying for a work permit, administrative dependency can still hamper reunified wives' labor participation by tying women's legal right to work to men's regular status (Lesselier 2008).

The administrative dependency fostered by family reunification also creates a gendered pathway into irregular status. Family reunification is not an automatic right conferred on migrants; on the contrary, states have imposed increasingly restrictive conditions that primary migrants have to meet before being allowed to bring family members to the destination country (Kofman 2004a). These conditions often require the sponsor to have a minimum period of prior residence, a stable income, and adequate housing in addition to regular legal status. The reunification of women whose husbands lack regular status or any of the other legal conditions must take place outside of the formal legal channel of reunification-for example, by overstaying an entry for tourism or other purposes (Lesselier 2008). Empirical research has shown that restrictive conditions do indeed lead to the incentivization of reunification outside or on the fringes of the legal system, especially among reunified wives who work upon arrival (González-Ferrer 2011b).

\subsubsection{Family Reunification Regimes and Configurations of Legal Status}

The specific legal rights granted to reunified migrants varies across destinations, giving rise to different configurations of legal status corresponding to different types of migrants in different countries. For the purposes of this chapter, it is useful to examine the configurations of legal status granted to reunified spouses in France, Italy, and Spain. In France, the legal reunification channel has consistently conferred the legal right to reside and work to reunified spouses (Lesselier 2008). Thus, women who follow the legal channel in France have legal authorization to work upon arrival. In Italy and Spain, however, immigration legislation has imposed a waiting period on reunified spouses' access to the labor markets; reunified spouses are thus likely to possess a residence permit but lack a work permit (GonzálezFerrer 2011b; Kofman 1999). The legal status granted to migrants in the category of "reunified spouses" and the concomitant legal access to the labor market thus varies across destinations. This variation is captured in the typology presented in Table 4.1.

Identical configurations of legal status can signal different types of migrants under different legal regimes, as is evident in Table 4.1. For example, migrants in France who lack a work permit - the legal status afforded to reunified spouses in

Table 4.1 Typology of female migrant types by legal status and country

\begin{tabular}{|c|c|c|c|}
\hline \multirow[b]{2}{*}{ Country } & \multicolumn{3}{|l|}{ Legal status } \\
\hline & Regular & Mixed & Irregular \\
\hline France & Reunified spouse & Student & Multiple \\
\hline Spain & Worker & Reunified spouse & Multiple \\
\hline Italy & Worker & Reunified spouse & Multiple \\
\hline
\end{tabular}


Italy and Spain — are likely to be students. In contrast, migrants in Spain and Italy with both a residence permit and a work permit - the legal status afforded to reunified spouses in France-are most likely labor migrants. There is thus substantial heterogeneity in the formal rights accorded to different admissions categories, making it imperative to examine both family context and legal status when considering the effect of family reunification on women's economic integration.

\subsection{Reunified Women and the Labor Market}

The economic and administrative dependency created by legal channels of family reunification may thus constrain women's legal participation in the labor force. Women have been marginalized in labor migration in part because many immigration policies implicitly assume that women are passive followers who do not seek employment (Kofman 2004a). Early research on the link between family ties and women migrants' economic participation tended to confirm this image. The "family migration model" (Sandell 1977) has traditionally seen migration as a disruptive event in women's work lives: women are assumed to move as part of a family migration unit, and thus will still migrate even if they are expected to have lower participation rates after arrival because the net benefit of a move for the family unit as a whole is positive (Mincer 1978; Sandell 1977).

Nonetheless, while the predominance of the family reunification channel for women has limited their ability to migrate and work independently, reunification does not necessarily preclude participation in the labor force. Research has shown that family migration, far from hampering a tied mover's economic participation, can often lead to women's employment: the "family investment model" contends that women whose spouses have the highest expected earnings in a destination may actually be more likely to participate in the labor force and to be employed as a way of supporting their husbands' investments in destination-specific human capital (Duleep and Sanders 1993). Women's family context and the potential labor-market success of a spouse thus emerge as important determinants of their labor-market performance.

Given that admission category/type of migration is not necessarily synonymous with the often-multifaceted motivations for migration, it is also important to be attentive to transitions over time in both legal status and labor-force participation after the year of arrival. Immigration policies with waiting periods build into their reunification regimes eventual transitions from the initial status defined by this entry category: reunified spouses can eventually apply for formal permission to enter the labor force. Women's and households' preferences about the allocation of female labor may also shift over time, meaning that even reunified spouses who do not initially work despite a legal authorization to do so may eventually end up in the labor force. Transitions into the labor market have been observed among reunified spouses, leading to the observation that family migration does not mean the end of labor migration, only its transformation because many family migrants eventually end up as de facto labor migrants (Kofman 1999). Indeed, women may have economic motivations for "associational" moves, and may use family reunification 
strategically to enter labor markets while at the same time following socially sanctioned channels of mobility (Kanaiaupuni 2000).

When women do work, a gendered labor market funnels women into specific jobs, mostly in the informal sector (Kofman 1999; Lesselier 2008). An example is the increasing demand for domestic workers, especially in Southern Europe, which draws women into low-skill, low-wage work (Kofman 1999, 2004b). Some countries, such as Italy and Spain, actively recruit female workers via employment quotas for low-skill domestic work (Kofman 2004b), while immigration legislation has also pursued high-skill migrants who tend to be male (Lesselier 2008; Raghuram 2004). Thus, when immigration policies allow female migrant labor, they actively channel women into specific low-wage sectors of the economy (with the exception of some female high-skill healthcare professionals, see Raghuram 2004). In countries such as France where legal channels of labor immigration do not include such gendered occupations, women migrating autonomously for work are especially likely to do so irregularly (Lesselier 2008). Immigration policies thus conspire with gendered labor demand to create differential legal immigration channels and pathways of irregularity for men and women.

\subsection{Limitations of Existing Research}

It is thus clear that the labor-market participation of female migrants is heterogeneous and is linked to their family context and the legal opportunities afforded by family-reunification policies, but much existing research on the legal status and immigrant economic incorporation has been blind to the gendered nature of immigration policies and the legal statuses they create. Most studies in the US context do not examine the possibility that the effect of different legal statuses might differ for men or women, nor do they consider alternative measures of economic incorporation such as labor-market participation or employment. Research in Europe has considered employment as an outcome in a context with institutional variation in labor markets across multiple contexts of reception but has not been able to measure legal status or its differential effects for men and women.

\subsubsection{Assuming Participation: Undocumented Status and Wages in the US}

Most studies of the link between legal status and migrant economic incorporation in the US find that undocumented status is associated with lower wages. Much of this research has used data from the Legalized Population Survey (LPS), conducted with a sample of undocumented migrants who were legalized by the 1986 Immigration Reform and Control Act (IRCA), to show that legalization was associated with an improvement in the economic opportunities among migrants whose status was adjusted (Kossoudji and Cobb-Clark 2000, 2002; Rivera-Batiz 1999); gaining regular legal status thus contributed positively to economic outcomes for migrants. 
At the same time, research has found that undocumented migrants faced additional deterioration in their earnings as a result of the stiffer penalties of this legislation, with employers passing on to them the costs and risks of unauthorized hiring (Donato and Massey 1993; Phillips and Massey 1999). Recent research, using recent longitudinal data with a larger comparison group and growth-curve modeling techniques, has continued to uncover disparities in earnings between documented and undocumented migrants (Hall et al. 2010).

The assertion of a negative effect of undocumented status must be re-examined in light of the gendering of both migration policies and labor-market participation. Unfortunately, the studies cited above focus only on the United States and almost exclusively on Mexican men. While undoubtedly an important case to study given high share of all immigrants in the US that this group makes up, it is also a case with a distinct history and social and economic infrastructure (Massey et al. 2002) that, in some ways, might limit its generalizability. In looking almost exclusively at wages, these studies implicitly select only migrants who are both active in the labor market and employed. While some studies do attempt to model the effect of selection into the migrant labor force on wages (Donato and Massey 1993; Massey 1987), the issue of differential migrant participation in the labor market is not addressed as a main topic of concern.

The assumption of both activity and employment might have held for earlier migration flows that were dominated by single, male workers (Piore's (1979) "birds of passage"), but most migration streams, even among Mexicans to the US, have diversified in recent years. Women have made up larger shares of both documented and undocumented Mexican migrants since 1986, and accounted for $45 \%$ of all Mexican migrants in the US in 2004 (Donato et al. 2008). Research has shown, though, that Mexican men and women in the US have different motivations for migration: men tend to be motivated by employment and often move alone, while women almost always follow another family member and thus tend to have family motivations for their migration (Cerrutti and Massey 2001). The gendered nature of work means that these female migrants have different labor profiles than their male compatriots (Donato et al. 2008). Cultural understandings of women's role in the family have limited Mexican migrant women's ability to work: only $47 \%$ of Mexican-born adult women in the US were in the labor force in 2006, compared to $88 \%$ of Mexican-born adult men (Donato et al. 2008). Motivations and value systems thus combine with reunification policies to limit women's participation in the labor market. Migrant women's economic integration in destination countries thus differs from that of men, and a focus on wages as the principal indicator of integration as in the US case excludes many women from the analyses.

\subsubsection{Ethnic Penalties on Employment in Europe, but Limited Measures of Legal Status}

The European research on immigrant economic incorporation helps to fill some of the blind spots in the American literature. Unlike in the US, studies of immigrant labor-market incorporation in Europe, where unemployment has historically been 
higher among both native-born and foreign workers, take the explanation of the likelihood of employment as a point of departure. This research has found, in general, that immigrants can often face an "ethnic penalty" (Heath and Ridge 1983) that translates into lower rates of employment compared to similar native-born workers (see Reyneri and Fullin 2011 for a review).

This general finding is tempered, however, by an insistence on cross-national variations in both the composition of migrant flows and institutional factors in the destination countries such as immigration policies, labor-market structures, and welfare regimes. Kogan (2006) finds that male migrants from sub-Saharan Africa in fourteen European countries are substantially disadvantaged in their probability of employment compared to native workers even after adjusting for human-capital endowments, while migrants from Asia and Latin America have lower rates of unemployment than natives. This study also finds significant institutional variation across countries in the employment penalty: migrants face a lower penalty in countries with high demand for low-skilled labor, in countries with more flexible labor markets, and in countries with "liberal" welfare regimes, such as the UK and Ireland, that emphasize mobility and flexibility (Kogan 2006).

These cross-national institutional differences make a strong case for the importance of studying employment as an indicator of the labor-market incorporation of migrants (González Ferrer 2006). Earnings assimilation is a good measure of adaptation in countries with a flexible labor market and a low minimum wage, where immigrants can compensate for initial lower host-country human capital by accepting lower pay (González Ferrer 2006); time spent in destination can help immigrants build human capital and "catch up" to natives in earnings, as has been found in the US (Borjas 1985, 1995; Chiswick 1978). Institutional features such as labormarket flexibility, however, vary cross-nationally, and in countries with less-flexible labor markets there has been little evidence of earnings assimilation. These are the labor markets identified by the cross-national research as subjecting immigrants to an employment penalty, and additional years in the destination might reduce earnings because of lack of initial attachment to the labor market (González Ferrer 2006). Assimilation in the probability of employment is thus the process of primary concern in understanding the labor-market performance of immigrants in highly regulated countries (González Ferrer 2006).

Unfortunately, the European cross-national research is hampered by a number of issues that limit its applicability to the study of the impact of legal status on immigrant economic incorporation. The biggest limitation is the inability of many studies to include direct measures of migrants' legal statuses. While comprehensive measures of legal status are increasingly available in a variety of surveys such as the Immigrant Citizen Survey (Huddleston et al. 2012), many studies simply compare legal immigrants to natives because more detailed data on legal status are not available. Study designs either precluded sampling irregular migrants (Kogan 2006) or did not include questions on legal status (Bernardi et al. 2011). Even though studying the impact of legal status might not be the principle aim of these studies, they either acknowledge that the absence of unauthorized migrants in the sample may bias results (Kogan 2006) or point to the presence of unauthorized migrants as 
potential explanations for their findings (Bernardi et al. 2011). It is thus implicitly assumed that the legal limitations faced by migrants who lack regular status relegate them to temporary, low-skilled jobs in the informal sector that offer little opportunity for mobility, and that this unobserved heterogeneity contributes to the poor outcomes observed for all migrants (Bernardi et al. 2011).

The lack of direct measures of legal status also hamper European studies' ability to examine the interaction between gendered family reunification policies, the legal statuses they create, and the differential economic outcomes of men and women. Those studies that do include measures of legal status often do not consider the gendered family and legal context of women's work. Studies in Spain using the Encuesta Nacional de Inmigración (ENI) show that lack of regular status constitutes both a barrier to employment and a brake on earnings for immigrants in Spain (Amuedo-Dorantes et al. 2013; Bradatan and Sandu 2012), but do not consider how the effect of legal status might vary for men and women nor do they differentiate between different types of migrants based on family context.

The literature reviewed above demonstrates that gender is a crucial factor to take into account when studying migration. While men certainly display a wide variety of motivations for migration, women's migration is extremely heterogeneous. Women are overrepresented in legal family-reunification flows, indicating that they face legal and social constraints on their mobility arising from the gendering of migration policies. At the same time, women also migrate outside of legal reunification channels, either as informal reunifiers or as autonomous migrants and with a wide variety of legal statuses. This diversity in types of female migration creates a variety of labor-market trajectories. The existing literature on migrant economic incorporation is largely unable to deal with this diversity as it does not account for either differential labor-force participation or the interaction between legal status and gender. This chapter will adopt an approach that is sensitive to the diversity of female migration types while also comparing women to men.

\subsection{Gender Norms, Family Reunification, and Work Among Senegalese Migrants}

Senegalese society is strongly stratified along gender lines, and this stratification has implications for Senegalese women's geographical mobility and economic integration. Toma (2012) reviews the literature on gender norms in Senegal and argues that gender strongly determines life prospects there. The "traditional conjugal contract" subordinates women to the authority of a breadwinner husband within the household and, by assigning women to household tasks, places them outside of public life (Toma 2012). The Senegalese nuptial system is patrilocal, with women residing with her husband's parents after marriage and providing labor to that household. Polygamy is also widespread in Senegal, and women must often inhabit the same household as their co-wives (Toma 2012). As a result of these gender 
norms, women's work outside the home is stigmatized. In addition, women tend to be less educated than men and thus less likely to participate in the labor force: according to Demographic and Health Survey (DHS) data, only 38\% of Senegalese women were working in 2006, compared to $66 \%$ of men (Toma 2012).

Research on family reunification among Senegalese migrants in Europe has found that Senegalese are reluctant to reunify wives of male migrants and has linked relatively low levels of reunification to traditional gender norms. Multi-sited families and conjugal distance are common in Senegalese society, meaning that spouses are used to physical separation (Beauchemin et al. 2013). While early Senegalese migration to France was based on a model of circular mobility wherein male migrants could regularly travel home to visit family and wives, increased state regulation and economic crisis in the mid-1970s (see Chap. 2) made this mobility more complicated. Some Senegalese migrants responded by reunifying their wives in France, but reunification was never a universal objective of Senegalese migrants partly because of the difficulty of reunifying polygamous households (Beauchemin et al. 2013). In the new destinations of Italy and Spain, different social origins meant that Senegalese migrants were not subject to the same traditional authority as Senegalese migrants in France, but Senegalese in new destinations also tended to be members of the Mouride Islamic brotherhood; combined with economic consideration, this religious adherence has made Senegalese migrants in new destinations also reluctant to bring their spouses from Senegal (Beauchemin et al. 2013). Evidence from the MAFE project indicates that only $13 \%$ of Senegalese migrants in Europe are a part of totally reunified families, while almost half live in a different country from their spouse(s) and child(ren) (Beauchemin et al. 2013).

Despite the reluctance of Senegalese migrants in Europe to reunify, research has also shown that family reunification remains an important channel for the migration of Senegalese women to Europe. Approximately $40 \%$ of women in the MAFE sample reunite with a partner at destination, and having a partner abroad is associated with substantially increased odds of migration among Senegalese women (Toma 2012). While female autonomy is low in Senegal and independent migration of Senegalese women is socially discouraged, there is some evidence of increasing migration of single women from Senegal (Beauchemin et al. 2013). Nonetheless, even single Senegalese women are unlikely to migrate without having ties to close family members at destination, indicating that even they face a degree of social control (Toma 2012).

The occupational profile of Senegalese migrants has varied over time and destinations. Senegalese men were commonly employed in low-skilled manual jobs in France, especially as garbage collectors in Paris (Barou 1993). Senegalese women started migrating to France in the 1970s under the auspices of family reunification as Senegalese men responded to the imposition of the requirements of residence permits in 1974 (see Chap. 2). (Timera 1997). The Senegalese women who came to France as reunified spouses eventually found work in unskilled service jobs (Barou 1993). In addition, high-skilled migrants and students from Senegal increasingly 
chose to go to France because of language ties and the similarities in the educational systems of the two countries (Toma 2012). These migrants often occupy whitecollar jobs in the public administration.

Senegalese migrants first started settling in Italy in the late 1980s and worked as informal street peddlers in Rome and on the beaches of Italy's tourist areas (Schmidt di Friedberg 1993). While this occupation is associated with irregular legal status and inability to find a better job in the Italian labor market (Riccio 2001; Schmidt di Friedberg 1993), other Senegalese migrants may embrace this occupation as a part of a "transnational livelihood" (Kaag 2008). After Italian regularization campaigns in the late 1980s and early 1990s, Senegalese also moved to the north of Italy to work for wages in manual jobs in small industry, construction, and food processing (Riccio 2008; Tall 2008), while many others remain traders.

In Spain, Senegalese, like other African migrants, are concentrated in unskilled jobs in agriculture, construction, and services (Pascual de Sans et al. 2000). Jobs in Spanish agriculture tend to be seasonal and pay low wages; construction work tends to pay better but it also temporary (Toma 2012). In addition to these manual jobs, Senegalese also work in street peddling in Spain (Toma 2012). Quantitative research on Senegalese occupational trajectories has confirmed that Senegalese migrants experience a drop in occupational status after arrival in Europe (Obucina 2013).

These descriptions indicate diversity in the contexts of reception, legal statuses, and socio-demographic characteristics among Senegalese migrants in Europe. While some research has suggested that sub-Saharan Africans living in Europe face difficulties in finding a job because of their low levels of qualifications (GonzálezEnríquez 2009), other studies have found that work is relatively easy to come by, partly as a result of the rejection of manual labor among native-born workers, but that the wages are low and the working conditions poor (Pascual de Sans et al. 2000). This inconsistency, while undoubtedly related to differences in timing of the studies, likely reflects a difference in labor-market regulations and the extent of informal economies, as Senegalese migrants tend to face higher unemployment in France (Tall 2008), but tend to have worse jobs when employed in southern Europe.

These variations are also related to legal statuses: Senegalese migrants have benefitted from multiple amnesty programs in southern Europe that have allowed transitions between formal and informal work, while they have been increasingly subject to restrictive immigration-control policies in France, which has likely made such mobility difficult. Finally, the characteristics of Senegalese migrants differ across these countries: Senegalese migrants in France tend to be more educated than those in Italy and Spain, where they may have the greatest ability to convert their human capital into employment (Castagnone et al. 2013). There is also an extreme gender imbalance across these countries: $45 \%$ of Senegalese migrants in France are women, compared to only $23 \%$ in Spain and 15\% in Italy (Toma 2012). This imbalance partly reflects differential preferences for family reunification across countries (Baizan et al. 2011; Kaag 2008) and thus has implications for both the legal statuses and the economic incorporation of Senegalese migrants. 


\subsection{Hypotheses}

The legal parameters governing family reunification and social parameters of the family context of individuals' migration are thus important determinants of both legal status of reunified spouses and their economic integration at destination. Given the gendered nature of family-reunification flows, these legal and social parameters are likely to be more important for women than for men. The economic and administrative dependency associated with family-reunification policies suggest that Senegalese women migrating for family reasons in the context of legal family reunification will be less likely to work upon arrival than either women migrating autonomously or men.

Cross-national variation in the rights accorded to reunified migrants suggests that different configurations of legal status in different countries will be related to both family reunification and economic integration (see Table 4.1). Regular status (having both a residence permit and a work permit) among Senegalese women in France is likely to indicate family reunification and thus be associated with lack of labor-market participation upon arrival. In contrast, mixed status (possessing a residence permit but lacking a work permit) among Senegalese women in Italy and Spain is likely to indicate family reunification and thus be associated with lack of labor-market participation upon arrival.

In contrast to Senegalese women who migrate for family reunification, Senegalese women who migrate autonomously will be more likely to be employed upon arrival. This category includes women with fully regular status in Italy and Spain. While women with mixed status in France are likely to be students, their relative autonomy may also make them more likely to seek to enter the labor market. Women with irregular status in all three countries may also seek to participate in the labor market; women with irregular status may be autonomous or non-formal family reunifiers, either of which could be consistent with economic motivations for migration.

Senegalese men's economic integration at destination, in contrast to that of Senegalese women, will not be as closely linked to channels of family reunification. Men's employment upon arrival will be more closely associated with cross-national variation in labor-market segmentation and demand for low-skilled labor as research has found that immigrants, even the undocumented, do not necessarily face an employment penalty in such economies; thus Senegalese men in Italy and Spain will be more likely to work than Senegalese men in France. Given the size of the informal economy in southern Europe, irregular status may also be associated with increased employment among men.

The empirical analysis will also focus on employment dynamics for both women and men. While family reunification may be related to inactivity among women during the year of arrival, it does not necessarily preclude eventual labor-market participation. Women who lack the legal authorization to work upon arrival can eventually apply for it, and those who possess work authorization from the beginning of their stay may also eventually work. Thus, Senegalese women who possess 
both a residence and work permit after the year of arrival are likely to make a transition into employment.

As Senegalese men are likely to be in the labor force from the beginning of their stay at a destination, the dynamic analysis will focus on transitions out of employment (or, equivalently, into unemployment). Senegalese men with regular status are likely to be the least likely to transition into unemployment because of provisions in immigration legislation that link continued possession of legal status to formal employment and vice versa, especially in southern Europe (see Chaps. 2 and 3). On the other hand, demand for low-skilled labor and the extent of the informal economy in southern Europe also make informal employment easier to access and irregular status less burdensome, meaning that irregular status may also be negatively associated with transitions to unemployment.

\subsection{Data and Methods}

This chapter uses the MAFE-Senegal data described in Chaps. 1 and 3. This chapter draws on the retrospective biographical data on Senegalese migrants' economic activities, union formation, child bearing, and administrative history. While the earlier chapters outline the sampling and data collection procedures, it is useful to note for the purposes of this chapter that women were oversampled in all locations to ensure sufficient numbers for separate gender analyses.

\subsubsection{The Analytic Sample}

The sample for the analysis in this chapter includes individuals who have migrated at least once to Italy, France or Spain while they were greater than 18 (see Chap. 1 for more details on the MAFE sampling and selection scheme). Returned migrants interviewed in Senegal are included if they spent at least a year in at least one of the destination countries. Individuals can have multiple periods of residence in or "trips" to one or more of these destination countries. The analytic sample thus comprises 7881 person-years and 727 trips: 3548 person-years in France (287 individual trips), 2258 person-years (221 individual trips) in Italy, and 2075 person-years (219 individual trips) in Spain. Sixty-five percent of respondents had only one trip, and an additional $21 \%$ had two trips.

The MAFE-Senegal data are well suited to this investigation because the multisited nature of the data collection reduces potential biases stemming from selective emigration and return (Massey 1987) through the inclusion of current and returned migrants. The data, in addition to reconstructing migrants' family and labor-market trajectories, also include extensive information on migrants' legal statuses during each year of residence abroad. Lack of such data on legal status has been a major 
impediment to investigations of the effect of legal status on labor-market performance of immigrants in Europe (Amuedo-Dorantes et al. 2013; González-Ferrer 2011a). The MAFE project also interviewed both women and men, allowing investigations of differential incorporation by gender. The sample includes $376(57 \%)$ men and 286 (43\%) women, although the weighted share of men is $70 \%$.

\subsubsection{Outcome Variables}

The analysis examines Senegalese migrants' labor-market performance in France, Italy, and Spain by focusing on three different outcomes: economic activity status during the year of arrival, transitions into (for women) or out of (for men) employment, and occupational category conditional on being employed.

\section{Economic Activity}

The MAFE questionnaire asked respondents to identify their principal activity for each period of their lives. Respondents could answer that they were studying, economically active, unemployed, homemaking, retired, or otherwise inactive. For this analysis, a categorical variable indicates whether migrants were working, unemployed, or economically inactive, with the last category including students, homemakers, retirees, and other inactive individuals. Table 4.2 presents weighted descriptive statistics for the sample and shows statistically significant bivariate gender disparities in economic activity during the year of arrival: $2.7 \%$ of women and $8.5 \%$ of men were unemployed $(p<.01), 38 \%$ of women and $76 \%$ of men were employed $(p<.001)$, and $59 \%$ of women and $15 \%$ of men were inactive $(p<.001)$ during the first year in destination.

Although this last category is heterogeneous across the entire sample, it is strongly gendered: $85 \%$ of men who were inactive during the year of arrival were students and $91 \%$ of all economically inactive person-years among men were spent studying, while $73 \%$ of women who were inactive during the year of arrival were homemakers and $77 \%$ of all economically inactive person-years among women were spent homemaking. Men never declared being a homemaker and were retired or otherwise inactive during 9\% of person years. Twenty-three percent of inactive women were students during the year of arrival but studying only made up 16\% of all inactive person-years among women.

The analysis uses two additional variables based on the economic activity variable: a variable capturing transitions into unemployment, if the categorical employment variable equaled "unemployed" at time $t+1$; and a variable capturing transitions into employment, if the categorical employment variable equaled "employed" at time $t+1$. These indicators serve as dependent variables in models for dynamic transitions into unemployment for men and into employment for women. 


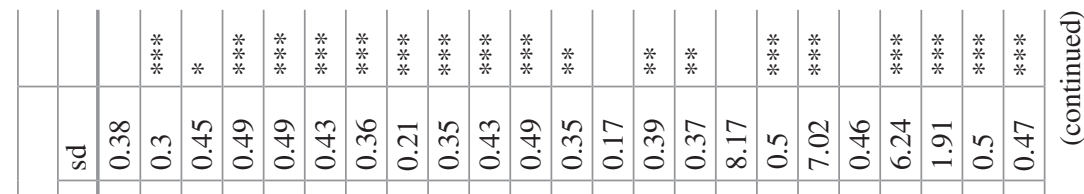 \\ 蔥

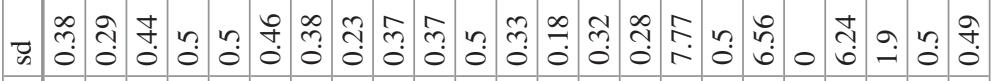

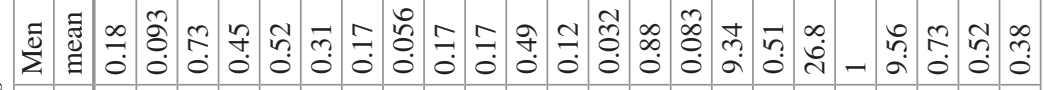
ร.

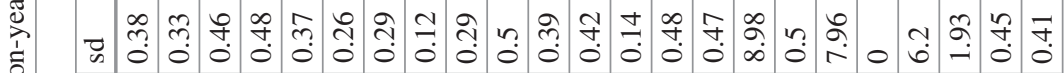

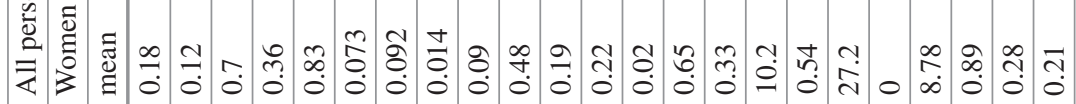

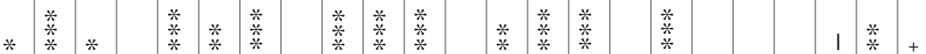

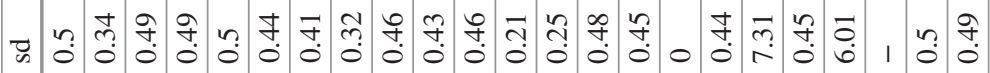
苛 Z

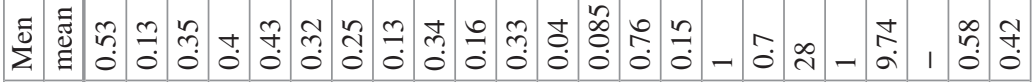

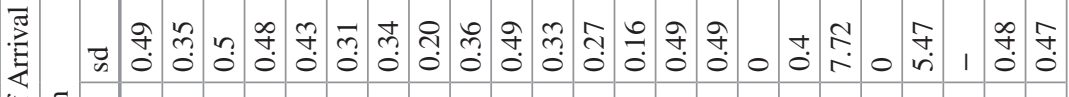

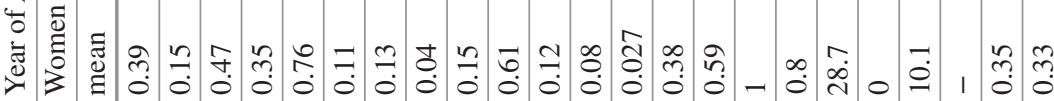




\begin{tabular}{|c|c|c|c|c|c|c|c|c|c|c|c|c|c|c|c|c|c|c|c|}
\hline & & & 菜 & $\underset{*}{*}$ & $\underset{*}{*}$ & + & * & * & 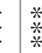 & & * & * & $\stackrel{*}{*}$ & $\stackrel{*}{*}$ & $\stackrel{*}{*}$ & & 蕃 & & \\
\hline & & $\vec{m}$ & 1 & $\vec{i}$ & $\cong$ & $\stackrel{f}{\stackrel{f}{0}}$ & $\because$ & $\frac{8}{8}$ & $\begin{array}{l}5 \\
0 \\
0\end{array}$ & $\stackrel{f}{\stackrel{f}{0}}$ & 突. & $\stackrel{\vartheta}{\circ}$ & $\dddot{n}$ & $\dddot{n}$ & $\stackrel{+}{0}$ & & 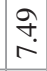 & & \\
\hline & 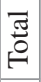 & $\begin{array}{l}\text { ॠ } \\
\text { छี }\end{array}$ & 1 & $\tilde{m}$ & $\bar{n}$ & co & f & 7 & 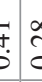 & $\begin{array}{c}\infty \\
-1 \\
\vdots \\
0\end{array}$ & 㐌 & $\stackrel{+}{0}$ & I) & ?̊ & $\stackrel{\infty}{0}$ & I & $\begin{array}{l}\infty \\
0\end{array}$ & $\begin{array}{l}\bar{\infty} \\
\infty \\
\sim\end{array}$ & \\
\hline & & $\vec{c}$ & 1 & $\begin{array}{l}\infty \\
\stackrel{0}{0} \\
\end{array}$ & $\stackrel{\text { N }}{=}$ & †. & ક̊ & co & 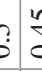 & $\stackrel{f}{\circ}$ & 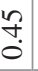 & $\stackrel{\text { If }}{\circ}$ & 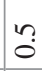 & 广̊. & $\stackrel{\text { f }}{\circ}$ & & $\begin{array}{l}\hat{\sigma} \\
-\end{array}$ & & \\
\hline & $\stackrel{\overline{0}}{\Sigma}^{\frac{0}{2}}$ & $\begin{array}{l}\text { శ్ } \\
\text { હี }\end{array}$ & 1 & $\stackrel{+}{a}$ & 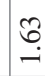 & 3 & $\overbrace{0}^{1}$ & a & $?$ & 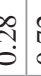 & 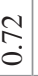 & ָे & $\stackrel{\infty}{+}$ & $\begin{array}{l}\infty \\
0 \\
0\end{array}$ & $\stackrel{\infty}{\stackrel{\infty}{0}}$ & 1 & 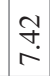 & 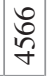 & \\
\hline$\hat{1}$ & & D & 1 & in & 年 & $\stackrel{\infty}{\substack{0 \\
0}}$ & లి & J & $\begin{array}{c}5 \\
0\end{array}$ & $\stackrel{f}{\circ}$ & 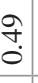 & f̊ & $\stackrel{a}{+}$ & ষ্ণ & ?ֶ. & & $\begin{array}{l}+ \\
\infty \\
0 \\
\dot{0}\end{array}$ & & \\
\hline 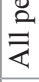 & है & $\begin{array}{l}\text { ॠ్ } \\
\text { छี }\end{array}$ & 1 & $\stackrel{\vec{\sim}}{+}$ & $\stackrel{\overbrace{}}{ユ}$ & $\frac{1}{0}$ & {$\left[\begin{array}{l}n \\
\infty \\
0\end{array}\right.$} & 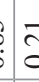 & 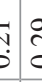 & 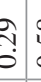 & $\stackrel{\infty}{n}$ & 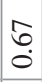 & $\stackrel{+}{\circ}$ & ஸ઼ & $\begin{array}{l} \pm \\
\infty \\
0\end{array}$ & 1 & $\begin{array}{l}\hat{n} \\
\text { ñ }\end{array}$ & $\frac{n}{m}$ & $\overline{8}$ \\
\hline & & & & $\stackrel{*}{*} *$ & 芩 & & 苂 & 苂 & $\stackrel{\hat{~}}{*}$ & & 㢹 & 荬 & $\begin{array}{l}\stackrel{*}{*} \\
\stackrel{*}{*}\end{array}$ & 荬 & & 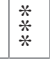 & & & \\
\hline & & $\vec{D}_{\infty}$ & సे & $\underset{i}{d}$ & $\stackrel{\infty}{-}$ & o & $\stackrel{f}{\circ}$ & 5 & $\stackrel{5}{\circ}$ & $\begin{array}{c}0 \\
0 \\
\end{array}$ & $\stackrel{\overbrace{}}{\stackrel{\Im}{0}}$ & 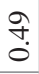 & $\dddot{n}$ & $\dddot{n}$ & $\stackrel{n}{0}$ & ઼ָ. & & & \\
\hline & 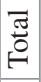 & 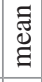 & के & $g^{2}$ & 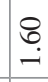 & శֶ. & กֶ. & $c$ & ș & 3 & $\begin{array}{l}\stackrel{?}{0} \\
0\end{array}$ & సे. & f. & $\tilde{n}$ & $\grave{0}$ & $\begin{array}{l}\infty \\
\infty \\
\infty \\
\infty\end{array}$ & 1 & $\widehat{N}$ & \\
\hline & & F & స̂. & $\underset{i}{\stackrel{\leftrightarrow}{2}}$ & $\stackrel{\infty}{\longrightarrow}$ & $\stackrel{\infty}{0}$ & $\stackrel{m}{0}$ & a & 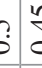 & $\stackrel{f}{\stackrel{5}{0}}$ & $\begin{array}{l}0 \\
+ \\
0 \\
0\end{array}$ & $\underset{⿱}{+}$ & $\because$ & $\stackrel{\infty}{+}$ & $\bar{m}$ & $\hat{ָ}$ & & & \\
\hline & $\sum^{\Xi}$ & 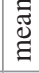 & $\stackrel{\infty}{0}$ & oิ & $\stackrel{?}{?}$ & ?ִ & $\stackrel{8}{\circ}$ & 8 & $\stackrel{t}{\dot{b}}$ & $\begin{array}{l}\hat{y} \\
\vdots \\
\end{array}$ & $\begin{array}{l}\hat{\sigma} \\
\dot{0}\end{array}$ & ก̃ & †े & 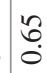 & $\begin{array}{l}\infty \\
0 \\
0\end{array}$ & 으 & 1 & $\widehat{\stackrel{\vartheta}{y}}$ & \\
\hline 8 & & $\vec{c}$ & $\stackrel{\sim}{0}$ & $\underset{i}{\stackrel{i}{0}}$ & $\frac{\pi}{0}$ & $\overbrace{0}^{\infty}$ & $\stackrel{\infty}{\stackrel{\infty}{0} .}$ & $\stackrel{\circ}{c}$ & $\stackrel{4}{\circ}$ & 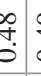 & 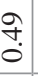 & $\stackrel{n}{\stackrel{n}{0}}$ & ?ִ & $\stackrel{m}{\stackrel{f}{0}}$ & సి & $\begin{array}{l}2 \\
i \\
\infty \\
\infty\end{array}$ & & & \\
\hline & & \begin{tabular}{|l}
$\bar{\Xi}$ \\
ઁ゙
\end{tabular} & $\frac{1}{0}$ & $\stackrel{\circ}{n}$ & $\stackrel{n}{n}$ & $=$ & $\underset{0}{\mathbb{O}}$ & I & $\begin{array}{lll}y & 4 \\
0 & 4 \\
0\end{array}$ & ? & $\begin{array}{l}0 \\
\stackrel{0}{0}\end{array}$ & $\stackrel{m}{\stackrel{0}{0}}$ & $\stackrel{\infty}{+} \underset{0}{+}$ & 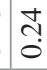 & $\tilde{\sigma}$ & 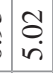 & 1 & ৪্ল & \\
\hline & & $\begin{array}{l}\frac{0}{2} \\
\stackrel{\pi}{7} \\
\end{array}$ & 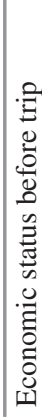 & 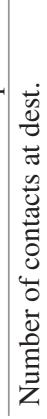 & 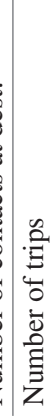 & 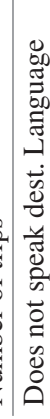 & 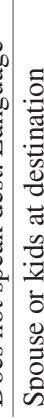 & 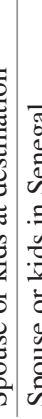 & 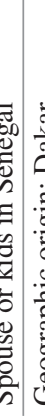 & 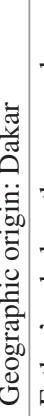 & 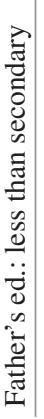 & 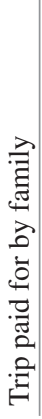 & 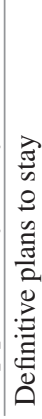 & 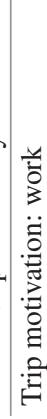 & 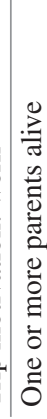 & 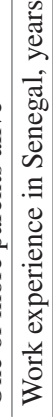 & 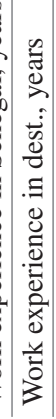 & $\mid$ & 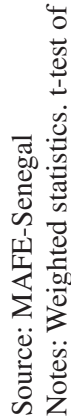 \\
\hline
\end{tabular}




\subsubsection{Predictor Variables}

\section{Legal Status and Context of Reception}

The key predictors in each model are variables measuring legal status. The analyses use the same typology of legal-status categories as presented in Chap. 3 and briefly restated here. A dichotomous variable indicates if a migrant entered the destination country at the start of the current trip with or without a visa. Annual indicators of residence and work permits combine to form a categorical variable capturing both forms of authorization. This categorical variable takes the values of "NRP_NWP" for migrants who lack both a residence permit and a work permit ("fully irregular status"), and "RP_WP" for migrants who possess both a residence permit and a work permit ("fully regular status"). "RP_NWP" indicates that migrants have a residence permit but lack a work permit ("mixed status"), a situation common among students and reunified family members in France, Italy, and Spain (Mezger and González-Ferrer 2013). While the combination of lacking a residence permit and possessing a work permit is theoretically possible and is declared in $4 \%$ of person years by Senegalese migrants, the immigration policies of the receiving countries have almost always made work permits conditional on possessing a permit to reside lawfully or possession of work permits have automatically made such residence lawful (see Chap. 2), and migrants may have declared this status because of recall bias or incomplete understanding of their statuses. The analyses thus exclude person-years in which migrants declared "NRP_WP" status from the analytic sample for this investigation.

Table 4.2 indicates that, during the first year in destination, Senegalese women are more likely to have fully regular status than men, while men are more likely to have fully irregular status; the proportions of women and men with mixed status during the first year are not statistically different. Approximately $17 \%$ of all personyears among both men and women display fully irregular status, with no significant gender difference. Women are significantly more likely to spend time in mixed status, accounting for $12 \%$ of their person-years compared to $9.3 \%$ of men's. Women spend a slightly higher proportion of person-years in fully regular status. The fully-regular category serves as the reference category in regression models. Regarding visa status, there is no statistically significant difference in the proportion of men and women arriving without visa.

The other key predictor variable is the context of reception, as captured by indicators for country of residence. Table 4.2 shows that women tend to be concentrated in France during the year of arrival: $76 \%$ of Senegalese women migrants live in France, as compared to $11 \%$ in Italy and $13 \%$ in Spain. Only $43 \%$ of trips for men start in France, with $26 \%$ starting in Italy and 22\% starting in Spain. A similar pattern for women holds across all person years: they are overwhelmingly concentrated in France ( $83 \%$ of person-years). Men also tend to spend more time overall in France across all person-years (52\%), while they spend $31 \%$ of person-years in Italy and $17 \%$ in Spain. 


\section{Location of Spouse/Partner}

A dichotomous variable indicates whether or not the migrant has a spouse and/or children living in the same destination. According to Table 4.2, 64\% of Senegalese women declared having a spouse and/or a child in the same destination at the year of arrival, while only $10 \%$ of men declared the same. A similar variable indicates whether or not the migrant has a spouse and/or children residing in Senegal: $42 \%$ of women and $47 \%$ of men declared having these family members at origin. An additional dichotomous variable indicates whether or not the migrant has at least one parent still alive in Senegal. All of the family variables are time-varying (Obucina 2013).

\section{Human, Social, and Migration-Specific Capital}

Variables indicating human capital during the year of arrival include years of education, ability to speak the language of the destination country (does not speak vs. speaks well or gets by), age at the time of the start of the trip, and years of work experience in Senegal prior to migration. Time-varying human-capital indicators include the number of years spent in the destination, the cumulative years of education acquired in the destination, and the cumulative years of work experience acquired in the destination; language ability can also vary over time. A variable measuring the number of family members and other close members of the migrant's personal network that live in the same destination country captures social capital and can vary over time. The number of trips a migrant has made indicates migrationspecific capital. Other variables capture migrants' motivations, which could be considered a kind of cognitive capital: a dichotomous variable indicates whether or not work was the main motivation for migration, and another dichotomous variable indicates whether or not the migrant plans to stay definitively in the current destination.

\section{Context of Exit}

Variables indicating the migrant's social and cultural context of exit include ethnicity (Wolof vs. other), religion (Mouride vs. other), and geographic origin (Dakar vs. other). Variables indicating the migrant's economic context of exit include selfreported economic status prior to migration (more than sufficient for daily needs and better than others in the same place vs. other), father's educational level (less than secondary school vs. secondary school or more, which is proxy for social class), and financial participation of family members in the financing of the current trip (yes vs. no). 


\subsubsection{Models}

Separate models for men and women are estimated for the outcomes of economic activity status and transitions to and from employment. Due to sample-size restrictions, separate models by gender for the occupational status outcome are not estimable; this model will thus include interactions between the gender and other key predictors.

\section{First-Year Economic Activity}

I estimate multinomial logistic regression models predicting economic activity status during the first year of residence in France, Italy, or Spain as specified by the following equation:

$$
\ln \left(\frac{\operatorname{Pr}\left(\text { Activity }_{i t 1}=i\right)}{\operatorname{Pr}\left(\text { Activity }_{t 1}=\text { Unemployed }\right)}\right)=\alpha+X_{1} \beta_{1}+X_{2} \beta_{2}+\left(X_{1} \times X_{2}\right) \beta_{3}+X_{4} \beta_{4}+X_{5} \beta_{5}+X_{6} \beta_{6}
$$

where $i$ indexes activity states unemployed, employed, and inactive at time $t=1 . X_{1}$ is a vector of indicators of legal status (visa and residence/work authorization), $\boldsymbol{X}_{2}$ is a vector of indicators of country of residence, and $\boldsymbol{X}_{1} \times \boldsymbol{X}_{2}$ represents the interaction between legal status and country of residence. $\boldsymbol{X}_{\mathbf{4}}$ is a vector of variables indicating human, social, and migration-specific capital. $\boldsymbol{X}_{\mathbf{5}}$ is a vector of variables indicating family links, and $\boldsymbol{X}_{\mathbf{6}}$ is a vector of variables capturing the migrant's context of exit. All variables in this model are measured at time $t=1$, the year in which the migrant arrives at the destination. I estimate separate models for men and women.

\section{Transitions into and out of Employment}

Discrete-time survival models estimate the risk of transitions either into or out of employment. The following model estimates the first transition out of employment for men:

$$
\ln \left(\frac{\operatorname{Pr}\left(\text { Enemployed }_{t+1}\right)}{1-\operatorname{Pr}\left(\text { _nemployed }_{t+1}\right)}\right)=\alpha+X_{1 t} \beta_{1}+X_{2 t} \beta_{2}+\left(X_{1 t} \times X_{2 t}\right) \beta_{3}+X_{4 t} \beta_{4}+X_{5 t} \beta_{5}+X_{6 t} \beta_{6}+X_{7 t} \beta_{7}
$$

where the outcome variable is a dichotomous indicator of unemployment at time $t+1$. All of the predictor vectors are as in the first model, except that some can vary over time; these are thus measured at time $t$. $\boldsymbol{X}_{\mathbf{4}}$ additionally includes the number of years spent at the destination, the cumulative time spent in employment or in formal 
studies at the destination, the prestige score of the migrant's current job, and a dichotomous variable indicating the activity status of the migrant in year $t$ (inactive vs. employed). $\boldsymbol{X}_{7}$ is a vector of time-counting variables indicating the duration at risk for falling into unemployment (number of years) and the number of activity spells. Only men who are employed or inactive are subject to the risk of falling into unemployment, and exit the risk set either through censoring or becoming unemployed.

The following model estimates the first transition into employment for women:

$$
\ln \left(\frac{\operatorname{Pr}\left(\text { Employed }_{t+1}\right)}{1-\operatorname{Pr}\left(\text { Employed }_{t+1}\right)}\right)=\alpha+X_{1 t} \beta_{1}+X_{2 t} \beta_{2}+\left(X_{1 t} \times X_{2 t}\right) \beta_{3}+X_{4 t} \beta_{4}+X_{5 t} \beta_{5}+X_{6 t} \beta_{6}
$$

where the outcome variable is a dichotomous indicator of employment at time $t+1$. The predictors are identical to those in model 2, with the exception of the employment-related variables, which are unmeasured for women because this model examines the risk of first entry into employment; the model for women does, however, include a variable indicating cumulative work experience in Senegal. Only women who are inactive or unemployed are subject to the risk of becoming employed, and exit the risk set either through censoring or becoming employed.

\subsection{Results}

\subsubsection{Gender, Partner Location, and Legal Status}

The MAFE data show a clear connection between partner location and the varying legal status configurations across countries as outlined in Table 4.1 that are indicative of family reunification for women in different. Figure 4.1 shows the legal status of Senegalese men and women during the year of their arrival in Europe, by their destination and the location of their partners. Women who rejoin a partner in France are overwhelmingly likely to have fully regular legal status during their year of arrival: $63 \%$ of women with a partner in France possess this status, compared to only $33 \%$ of women in France without a partner in that location. Senegalese women with fully regular status in France and a spouse in that destination are thus likely to have accessed this status through legal channels of family reunification as France's immigration policies allow both residence and work authorizations for reunified spouses.

In contrast, Senegalese women going to Spain or Italy to rejoin a partner are likely not to have fully regular status, and results are indicative of the operation of both legal and irregular channels of reunification. Mixed status-possessing a residence permit but lacking a work permit-is the most common for Senegalese women with a partner in Italy, indicative of family reunification in a legal context 


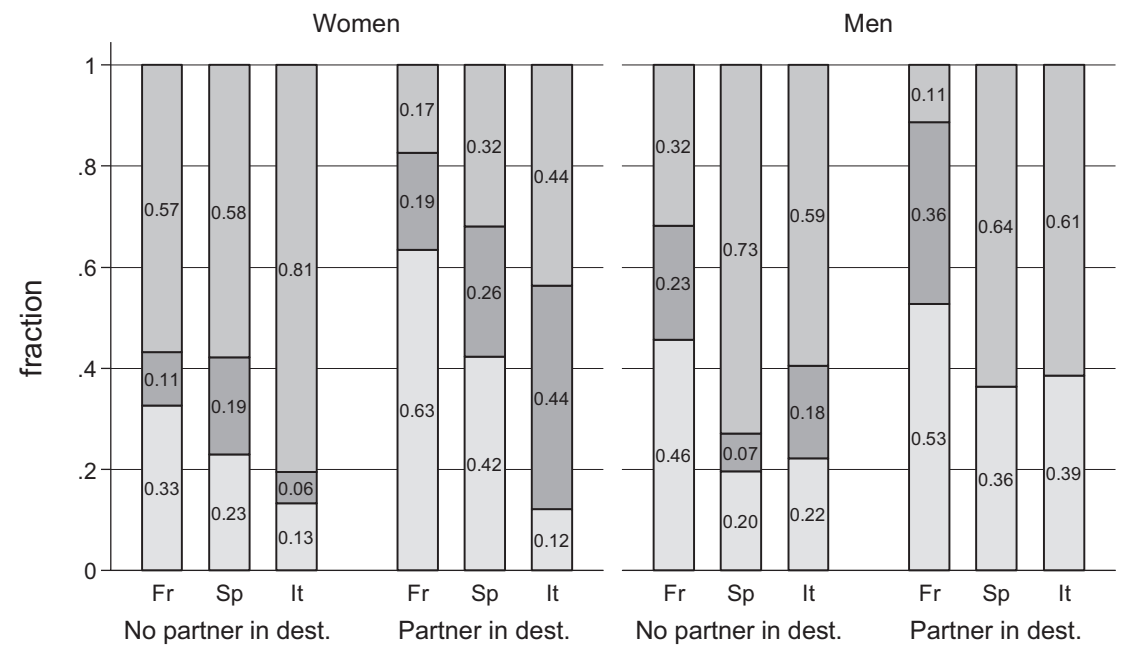

$\square$ Fully regular

Mixed

Fully irregular

Fig. 4.1 Legal status at arrival by gender, destination, and location of spouse. (Source: MAFESenegal. Notes: Weighted data)

that imposes a waiting period. Irregular status is also common among women joining a partner in Italy, which suggests the operation of an irregular-reunification pathway. In Spain, more than half of Senegalese women rejoining a partner report having either mixed or fully irregular status upon arrival, indicating the prevalence of both the legal channel of family reunification that imposes a work-authorization waiting period (giving rise to mixed status) and an irregular pathway of reunification. The figure suggests that the distribution of legal statuses during the year of arrival among Senegalese men conditional on partner location does not vary as much as for women.

Examination of women's motivations for migration along with the location of their partner and elucidates the link between family-reunification policies and women's first-year legal status. Figure 4.2 shows that women who migrate for family reasons and join a partner at destination are likely to have the configurations of legal status indicative of family reunification (fully regular status in France and mixed status in Italy and, to a slightly lesser extent, Spain). In contrast, women with a partner at their destination who migrate for work reasons are far more likely to have fully irregular status in all destinations, indicating a willingness to circumvent legal channels of family reunification that may inhibit their ability to work upon arrival. These descriptive findings are suggestive of the link between women's legal status during the year of arrival and the gendered channel of family reunification. 


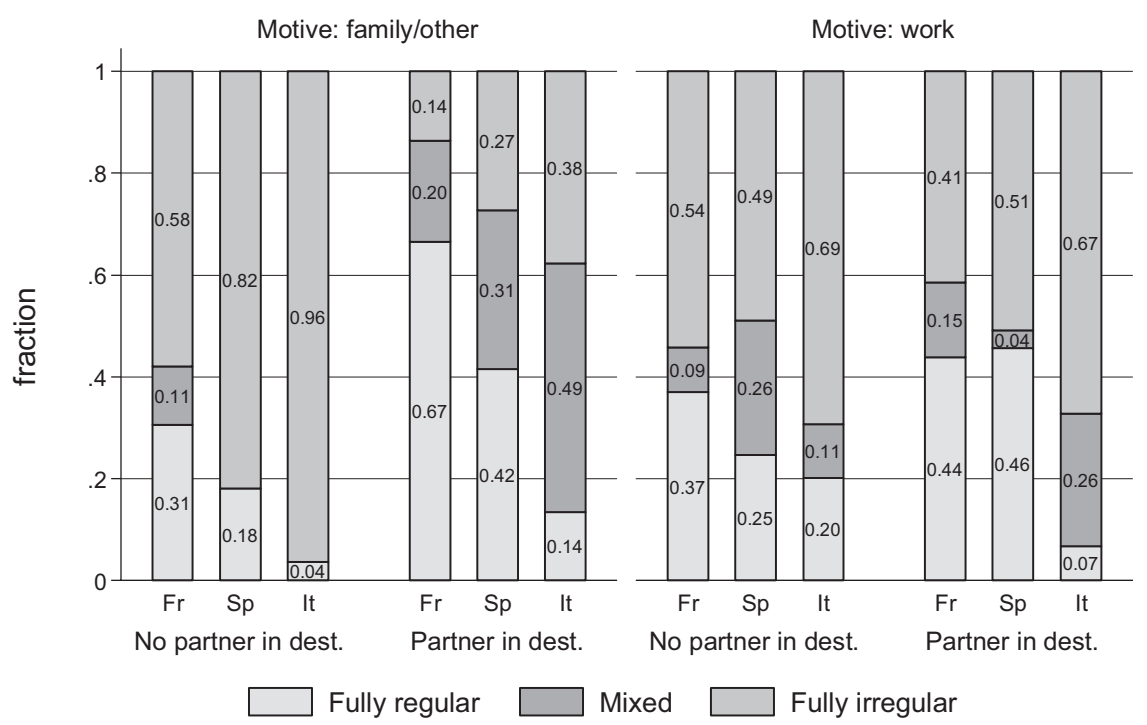

Fig. 4.2 Legal status among Senegalese women during year of arrival, by destination, partner location, and migration motivation. (Source: MAFE-Senegal. Notes: Weighted data)

\subsubsection{First-Year Economic Activity}

Legal status was hypothesized to have different effects for Senegalese men's and women's economic status during the year of arrival at destination. Descriptive statistics largely support this view, with much greater variation in economic activity across women's legal statuses than men's.

The descriptive statistics in Table 4.2 demonstrate differences in Senegalese men's and women's labor-force participation during their year of arrival at destination: women are more likely to be inactive, and, among those in the labor force, men are more likely to be unemployed. Figures 4.3 and 4.4 show additional variation in labor-force participation and employment among both men and women by their legal status upon arrival and their destination country. The first figure shows that Senegalese men in France across all legal statuses tend to be inactive more frequently than Senegalese men in Italy or Spain, reflecting the fact that there is a significant flow of Senegalese students to France given the colonial and linguistic links between the two countries. Male migrants also tend to have a higher rate of inactivity in Spain and Italy when they have a mixed status upon arrival. A very small proportion of Senegalese men with fully regular status are inactive in Italy or Spain. Unemployment rates among men are quite low across countries and legal statuses. Having fully irregular legal status is positively associated with unemployment in Italy during the year of arrival, while a higher risk of unemployment is associated with having a mixed status in Spain. 


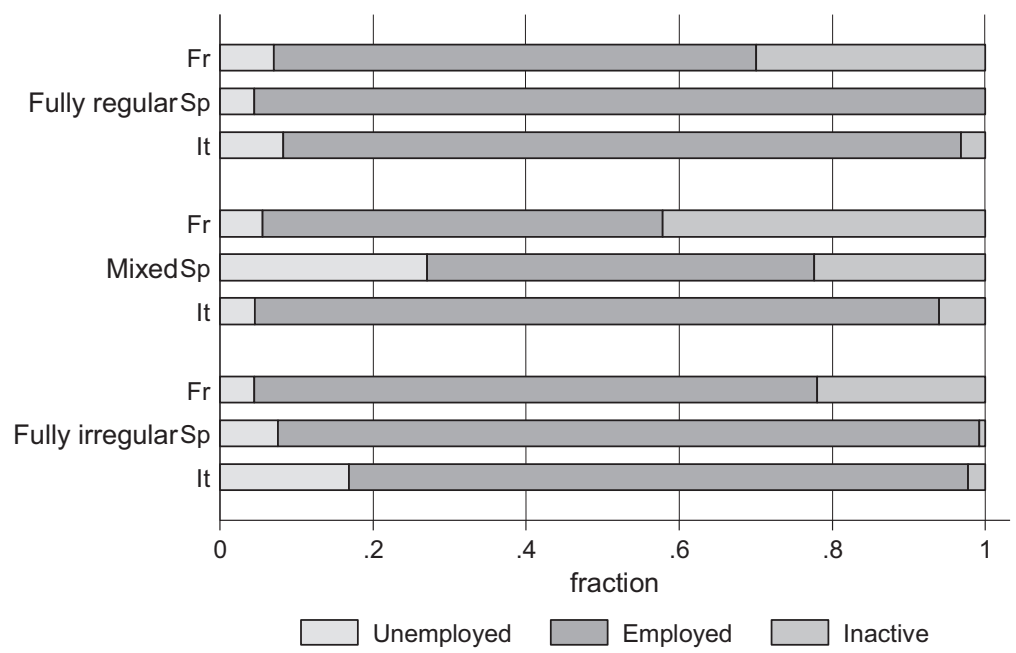

Fig. 4.3 First-year activity status by legal status and country of residence, Senegalese men. (Source: MAFE-Senegal. Weighted data)

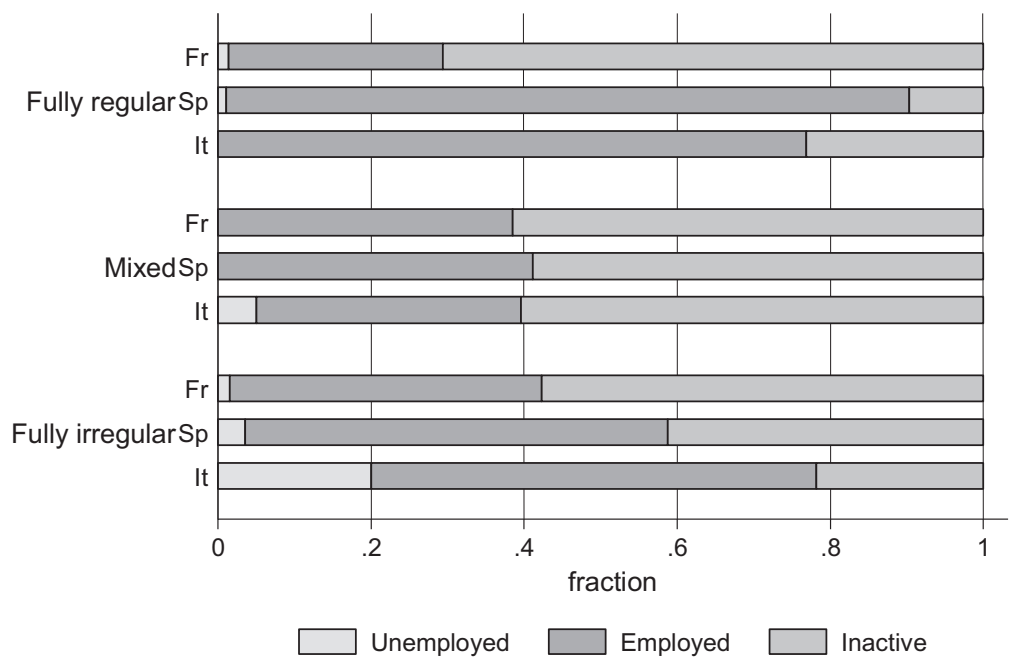

Fig. 4.4 First-year activity status by legal status and country of residence, Senegalese women. (Source: MAFE-Senegal. Weighted data)

Figure 4.4 shows a different pattern for women: rates of labor-force participation and employment vary strongly by country of residence and legal status. Senegalese women with mixed status (RP_NWP) have the highest rates of inactivity, and these rates are higher in Spain and Italy than in France. Among Senegalese women in France, those with fully irregular status have the lowest rate of inactivity, while 
those with fully regular status have the highest rates of inactivity. The pattern for Italy and Spain is reversed: female migrants with fully irregular or fully regular statuses have the lowest rates of inactivity. As with male Senegalese migrants, having fully irregular status in Italy during the year of arrival seems to increase the risk of unemployment for those women in the labor market, especially compared to female migrants with fully regular status in Italy, who experience little unemployment during the year of arrival. Female migrants in Spain and France seem to face low levels of unemployment across legal statuses.

Results from the multinomial regression models for men and women also suggest that the effect of legal status on first-year economic activity is gendered. Table 4.3 displays results from the separate multinomial logistic regressions of firstyear activity status for Senegalese men and women. For Senegalese men, having mixed legal status (RP_NWP) is positively associated with being inactive: compared to male migrants with fully regular status, male migrants who lack only a work permit are six percentage points more likely to be inactive. Conversely, legal status does not have a statistically significant association with probabilities of working or being unemployed during the year of arrival for men.

While the effect of legal status on men's first-year activity is limited, legal status is more consistently associated with first-year activity for Senegalese women. Having mixed (RP_NWP) status is positively associated with being inactive compared to having fully regular status (RP_WP), although only at $p<.1$, and this effect is offset by a negative association between mixed status and the probability of employment. Women with fully irregular (NWP_NRP) status face a higher risk of unemployment compared to women with fully regular status (RP_WP): lacking both residence and work authorization is associated with a five-percentage-point increase in the probability of being unemployed compared to being inactive or employed. Entering the country without a visa has no effect on any of the outcomes for either men or women. The effect of legal status on first-year economic activity thus varies by gender. Lacking only a work permit increases the probability of being inactive for both men and women, indicating the role of student migration for men and family reunification for women. Other predictors in this model lend credence to this interpretation. Years of education is significantly positively related to inactivity and negatively related to employment for men, while years of work experience in Senegal is associated with increased employment and decreased inactivity. Acquired human capital thus has opposite effects: those male Senegalese migrants that are more highly educated tend to be economically inactive students during their year of arrival, while those with acquired employment experience tend be economically active and working.

Other predictors in the model are also suggestive of distinctive profiles of labormarket participation in keeping with family reunification for women. Among women, those who indicated work as the primary motivation for their migration are 17 percentage points less likely to be inactive than those women who indicated family as the primary motivation. In addition, women who intend to stay definitively at 


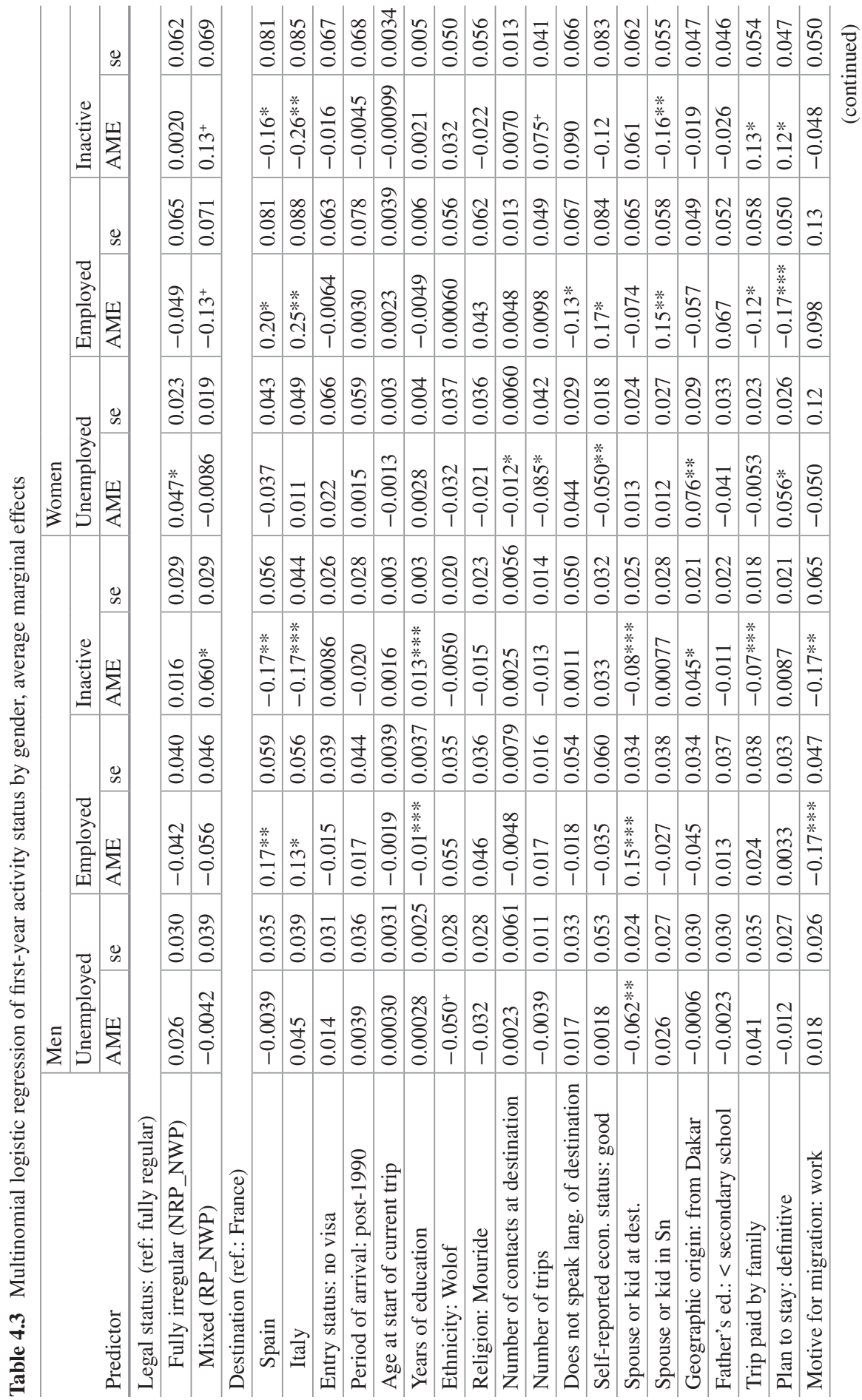




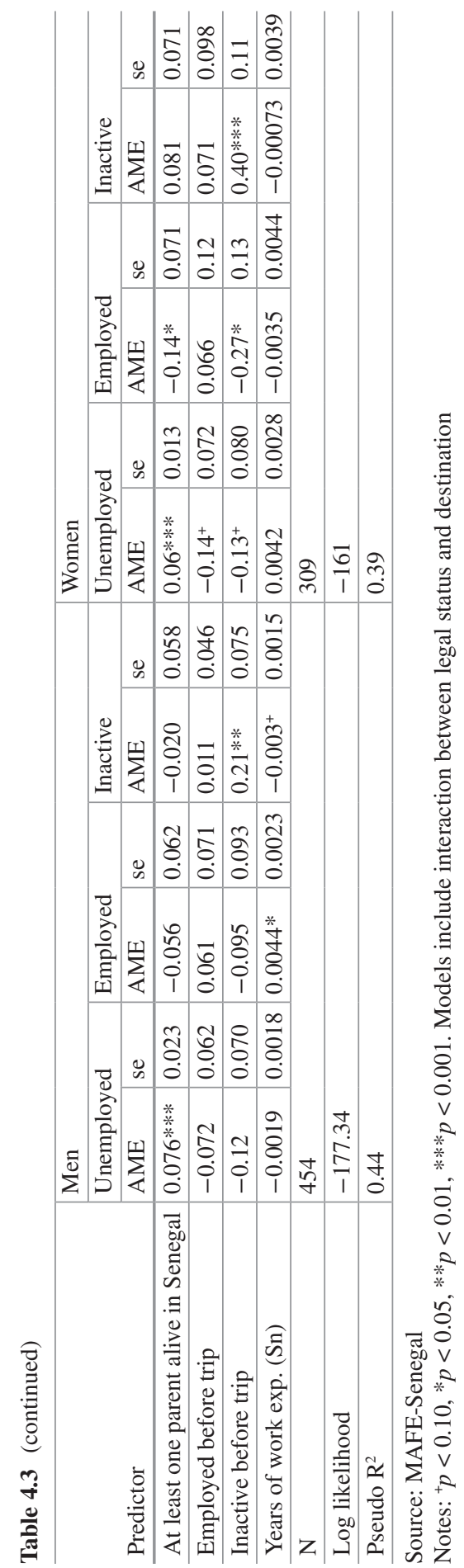


the destination and those whose families contributed financially to the trip ${ }^{1}$ are more likely to be inactive and less likely to be working. These associations between motivations, intentions, family financial participation and the likelihood of inactivity are indicative of family reunification. Interestingly, having a spouse and/or children at the destination had no direct effect on women's first-year economic activity net of legal status and other predictors, suggesting that direct measures of women's legal status and motivations are more important predictors of economic participation.

Other predictors were indicative of autonomous-migration profiles. Those women with a spouse or children in Senegal are less likely to be inactive and more likely to be working, indicating that they are probably independent pioneer migrants who migrated, in part, to support family in Senegal through working in Europe; for men, having a spouse or child in the same destination is positively predictive of employment and negatively predictive of both inactivity and unemployment. While legal status and other predictors define distinctive profiles for inactive migrants among both men and women, legal status is not related to employment for active men. It does seem, however, to structure women's employment chances: female migrants with fully irregular status are more likely to be unemployed.

The effects of legal statuses vary across destinations, but more so for women than for men. Table 4.3 also shows significant variation in the probabilities of firstyear activity status between contexts of reception. For both men and women, compared to their compatriots in France, Senegalese in Italy and Spain are less likely to be inactive and more likely to be employed during their first year of residence. Country of residence does not have a significant relationship with unemployment for either men or women. Given the variation in first-year activity status by both legal status and country of residence, the model includes an interaction between these predictors that can help us examine how the effect of legal status varies by country of residence. Table 4.4 displays the average marginal effects of legal status by country of residence for both men and women. The top panel of the table shows that this interaction does not produce statistically significant variation in the effects of legal status for men.

For Senegalese women, on the other hand, variation in the effect of legal statuses on first-year economic activity across destinations is consistent with different configurations of legal status for reunified migrants in different countries. The bottom panel of Table 4.4 shows that the effects of legal status do vary by destination for women. For women in France, not having fully regular legal status is associated with a decrease in the probability of being inactive: women with mixed (RP_NWP) status are 21 percentage points less likely to be inactive than women with fully regular status, and women with fully irregular status are 24 percentage points less likely to be inactive than women with fully regular status. These lower inactivity rates for women without fully regular status in France are offset by a relative increase in the

\footnotetext{
${ }^{1}$ Previous empirical research with the MAFE data has shown that husbands overwhelmingly participate in the decision-making for their wives' migration (Toma 2012). Family financial contributions to women's migration also come mostly from husbands: $74 \%$ of Senegalese women who reported such financial contributions received them from their partners.
} 


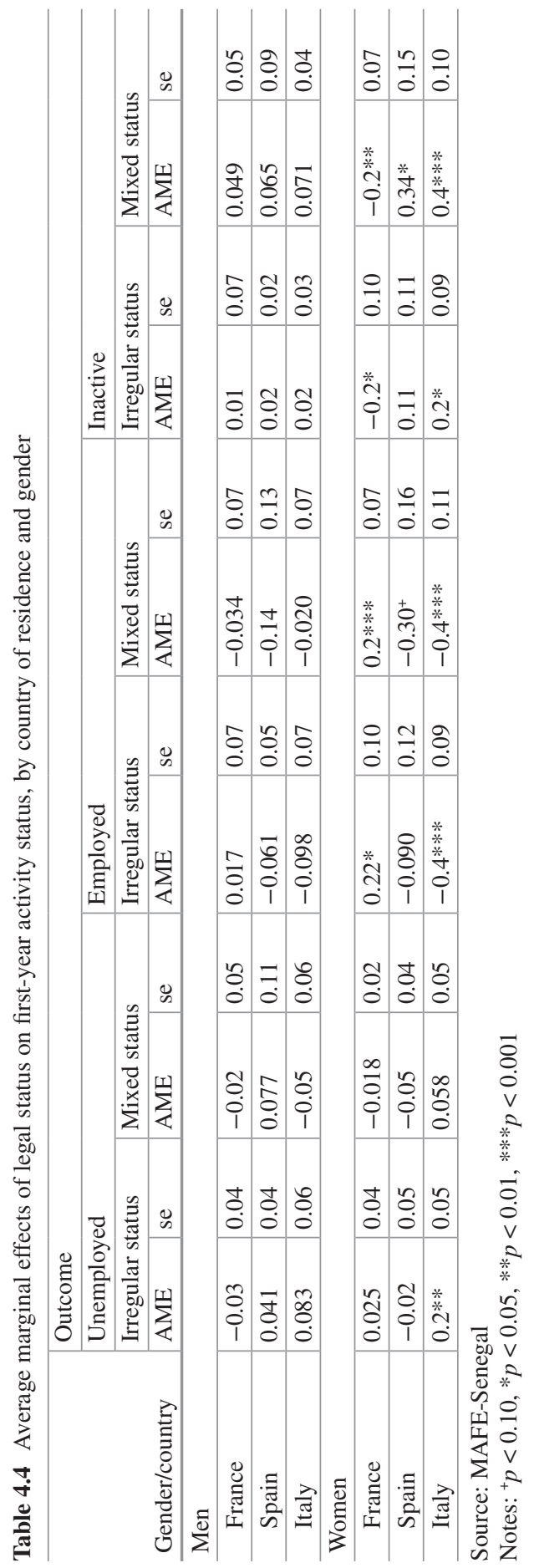


probability of employment: women with mixed or fully irregular status have employment probability roughly 22 percentage points higher than fully regular women in France, while legal status has no effect on unemployment for women in France. These findings are indicative of their migration via the legal reunification channel, which confers fully regular legal status. The lower activity rate of these likely reunifiers supports previous findings that reunified women are less likely to participate in the labor force because of administrative and economic dependency.

The association between legal status and inactivity among Senegalese women in Italy and Spain is also consistent with legal channels of family reunification. Women with mixed legal status in Italy and Spain are more likely to be inactive than women in those countries with fully regular status. These higher inactivity rates translate into a negative effect of mixed legal status on employment in both of these countries. As in the case of France, these results are consistent with the channel of family-reunification in these countries. Italy and Spain differ from France in the specific configuration of legal status associated with the family reunification channel: they both impose a waiting period on the reunified spouses' applications for a work permit. The lack of a work permit among otherwise legal migrants is a sign of reunification and limited rights of formal participation, which result in lower participation in the labor force for reunified Senegalese women in southern Europe.

Senegalese women with legal statuses upon arrival that are indicative of nonreunification pathways are more likely to attempt to work. Mixed or irregular statuses are associated with employment among Senegalese women in France, indicating that students (who generally lack a work permit) and migrants with irregular status are more likely to work than reunified spouses, and this in spite of their lack of formal authorization to do so. In contrast, having fully regular status is predictive of employment in both Italy and Spain; unlike in France, where this status is associated with family reunification, this association suggests that Senegalese women might be able to access formal channels of labor recruitment, perhaps through quotas for domestic workers.

These results show a fairly simple pattern: Senegalese women who have legal statuses consistent with family reunification tend to have higher rates of inactivity than Senegalese women with other legal statuses. The specific configuration of legal statuses associated with reunification varies across destinations, though, giving rise to different associations between particular statuses and the probability of inactivity in different countries. These results also strongly suggest the heterogeneity of Senegalese women's legal statuses and a systematic association between nonreunification statuses - even those that do not include formal residence and/or work authorization - and the propensity to be employed upon arrival. In contrast, the labor-force participation and employment of Senegalese men is not as sensitive to variation across legal statuses or destinations, indicative of a near-universal motivation to work (with the possible exception of male students in France). 


\subsubsection{Transitions out of Employment for Men}

The dynamic model of transitions into unemployment for Senegalese men shows that lack of fully regular legal status does not increase the likelihood of losing a job, nor does possessing fully regular status increase the likelihood of keeping a job. Table 4.5 presents results for the discrete-time survival analysis of transitions into unemployment for men. These results show that mixed or fully irregular legal status is not associated with a statistically significantly different risk of falling into unemployment compared to fully regular status, nor is having entered without a visa predictive of this transition. Senegalese men in Spain face a 2.3 percentage-point higher risk of falling into unemployment than Senegalese men in France. Interactions between legal status and country of residence do not show any significant effects. Formal, legal barriers to transitions out of employment thus seem to be limited for Senegalese men.

Indeed, few predictors in this model have a significant association with the risk of falling into unemployment, which is due in part to the rarity of the transition: only $8 \%$ of subjects eventually fail, and the survivor function after 7 years-the median duration at risk for unemployment-is $95 \%$. The risk of transitioning to unemployment is marginally higher for more recent arrivals, perhaps suggesting secular declines in labor-market conditions. The risk of unemployment also increases with the number of activity spells and the prestige score of jobs, indicating that frequent change of jobs and having a "better" job increase the likelihood of becoming unemployed. This pattern may indicate that Senegalese men may indeed experience a tradeoff between employment and job quality: bad jobs are easier to get and to hold on to than good jobs, as is suggested by the literature (Fullin and Reyneri 2011). Conversely, male migrants whose families participated in financing their trip are less likely to become unemployed, indicating that such migrants may be more likely to keep jobs because, in part, they face pressure to "pay off" this investment through remittances (Chort et al. 2012).

\subsubsection{Transitions into Employment for Women}

Transitions to employment for women are suggestive of the eventual transformation of reunified spouses into labor migrants. The probability of a transition into employment among women is much higher than the transition examined for men: after the median duration of time at risk for becoming employed (4 years), the survivor function is only $62 \%$; the figure falls to $30 \%$ after 10 years. The baseline risk for women is thus quite high, indicating that the majority eventually experience a transition into economic activity.

The dynamic model of women's transitions into employment indicates that secure legal status is a strong predictor of eventual work. Table 4.5 presents average marginal effects for the discrete-time survival analysis of transitions into employment 
Table 4.5 Discrete-time survival analysis of transitions into and out of employment by gender, average marginal effects

\begin{tabular}{|c|c|c|c|c|}
\hline \multirow[b]{3}{*}{ Predictor } & \multicolumn{2}{|l|}{ Men } & \multicolumn{2}{|l|}{ Women } \\
\hline & \multicolumn{2}{|c|}{ Unemployment } & \multicolumn{2}{|c|}{ Employment } \\
\hline & AME & se & AME & se \\
\hline \multicolumn{5}{|l|}{ Legal status (ref.: fully regular) } \\
\hline Fully irregular (NRP_NWP) & -0.0039 & 0.0073 & -0.043 & 0.044 \\
\hline Mixed (RP_NWP) & -0.0085 & 0.0091 & $-0.10 * * *$ & 0.031 \\
\hline \multicolumn{5}{|l|}{ Destination (ref.: France) } \\
\hline Spain & $0.023^{*}$ & 0.0089 & 0.0097 & 0.053 \\
\hline Italy & 0.011 & 0.0089 & -0.072 & 0.047 \\
\hline Entry status: no visa & -0.00031 & 0.0037 & 0.093* & 0.038 \\
\hline Years in dest. & -0.0079 & 0.0068 & 0.0050 & 0.0097 \\
\hline Duration at risk & 0.00049 & 0.0027 & 0.0076 & 0.0095 \\
\hline Period of arrival: post-1990 & $0.0092^{+}$ & 0.0049 & $0.10^{* * *}$ & 0.027 \\
\hline Number of act. spells & $0.022 * * *$ & 0.0036 & $0.064 * * *$ & 0.015 \\
\hline Age at start of current migration spell & -0.00060 & 0.00040 & -0.0014 & 0.0018 \\
\hline Years of education & -0.00024 & 0.00056 & $0.0072 * *$ & 0.0027 \\
\hline Ethnicity: Wolof & 0.0033 & 0.0064 & $-0.034^{+}$ & 0.021 \\
\hline Religion: Mouride & -0.0078 & 0.0060 & -0.026 & 0.042 \\
\hline Years of ed. in dest. & 0.0070 & 0.0070 & -0.0037 & 0.0073 \\
\hline Number of contacts at destination & $-0.0019^{+}$ & 0.0011 & $0.0095 *$ & 0.0047 \\
\hline Number of trips & -0.00016 & 0.00100 & 0.043 & 0.027 \\
\hline Does not speak language of destination & -0.0068 & 0.0053 & -0.0078 & 0.047 \\
\hline Work exp. at dest. & 0.0086 & 0.0080 & - & - \\
\hline Unemployed & - & - & \multicolumn{2}{|l|}{ Ref. } \\
\hline Employed & \multicolumn{2}{|l|}{ Ref. } & - & - \\
\hline Inactive & -0.0031 & 0.0089 & -0.093 & 0.067 \\
\hline Manual occupation & 0.0030 & 0.0045 & - & - \\
\hline ISEI & $0.00028 *$ & 0.00013 & - & - \\
\hline Spouse or kid at dest. & 0.0019 & 0.0037 & 0.0063 & 0.036 \\
\hline Spouse or kid in Sn & -0.0047 & 0.0046 & 0.038 & 0.044 \\
\hline Geographic origin: from Dakar & -0.00082 & 0.0044 & 0.023 & 0.031 \\
\hline Father's ed.: < secondary school & -0.0044 & 0.0036 & 0.0096 & 0.027 \\
\hline Trip paid by family & $-0.013 * *$ & 0.0049 & 0.0012 & 0.028 \\
\hline Plan to stay: definitive & 0.0035 & 0.0040 & $0.055^{+}$ & 0.029 \\
\hline Motive: work/better life & -0.0052 & 0.0038 & 0.045 & 0.034 \\
\hline Work exp. in Sn (years) & - & - & $0.0055^{* *}$ & 0.0017 \\
\hline Self-reported econ. status: good & - & - & -0.018 & 0.051 \\
\hline $\mathrm{N}$ (person-years) & \multicolumn{2}{|l|}{4010} & \multicolumn{2}{|l|}{819} \\
\hline Events & \multicolumn{2}{|l|}{36} & \multicolumn{2}{|l|}{90} \\
\hline Log likelihood & \multicolumn{2}{|l|}{-131.21} & \multicolumn{2}{|l|}{-231.49} \\
\hline Pseudo $\mathrm{R}^{2}$ & \multicolumn{2}{|l|}{0.36} & \multicolumn{2}{|l|}{0.18} \\
\hline
\end{tabular}

Source: MAFE-Senegal

Notes: ${ }^{+} p<0.10,{ }^{*} p<0.05, * * p<0.01,{ }^{* * *} p<0.001$. Models include interaction between legal status and destination 
for women and shows significant effects of legal status. Compared to fully regular status, mixed (RP_NWP) status is associated with a ten-percentage-point decline in the risk of becoming employed, while there is no average statistically significant difference between fully irregular and fully regular status. Additional statistical tests indicate that the difference in AMEs between fully irregular and mixed statuses is significant at $p<0.10$. While mixed status is associated with family reunification and thus inactivity during the year of arrival in Italy and Spain, most $\left(95 \%{ }^{2}\right)$ women with mixed status eventually transition into fully regular status and thus gain access to the labor market (perhaps not surprising given the EU Council Directive 2003/86/EC of 22 September $2003^{3}$ on the right to family reunification, which foresees that exclusion from the labour market is at most permitted during the first year). Reunified Senegalese women in France have this status from the start of their stay and thus face no legal barriers to eventual employment even if their economic and administrative dependence constrains their work initially. These results indicate that Senegalese women who possess or access fully regular status in the process of family reunification are likely to make an eventual transition to employment.

Irregular entry status, on the other hand, is also significantly predictive of the risk of becoming employed: having entered without a visa is associated with an increase of 9.3 percentage points in the hazard of becoming employed. Thus, women who entered without a visa are likely to become employed. While seemingly at odds with the finding that current fully regular status is associated with employment, the relationship between irregular entry and eventual employment may be indicative of interlinked regularization and employment strategies: women who enter outside of legal channels may pursue regular status as part of an employment-focused trajectory.

Variation in the effects of legal statuses for women across destinations supports the interpretation that reunified wives are likely to make a transition into employment, especially in France. Table 4.6 displays the substantial variation in the effects of legal-status categories in different destinations. Having mixed status in France is associated with a lower risk of becoming employed than having fully regular status, as is having fully irregular status. Women with fully regular status in France-who are likely to have entered through the channel of legal reunification and were the most likely to be inactive during the year of arrival-are thus the most likely to undergo a transition to employment.

The results for the southern European destinations are more complicated. Mixed status is significantly negatively related to the transition to employment in Spain while there is no association in Italy. In contrast, there is no statistically significant effect of fully irregular status in Spain, while fully irregular status in Italy is associated with an increase in the risk of employment of 20 percentage points. Senegalese women in Spain with regular status are thus the most likely to make a transition to employment, and this group is likely to be composed of both reunified spouses who gained work authorization after arrival and labor migrants with regular status- the

\footnotetext{
${ }^{2}$ Tabulation available upon request.

${ }^{3} \mathrm{http} / / /$ eur-lex.europa.eu/legal-content/EN/TXT/?uri=CELEX:32003L0086
} 
Table 4.6 Average marginal effects of legal status on risk of employment for women, by country of residence

\begin{tabular}{|c|c|c|c|c|c|c|}
\hline \multirow[b]{3}{*}{ Destination } & \multicolumn{6}{|c|}{ Legal-status variable } \\
\hline & \multicolumn{2}{|c|}{ Irregular status } & \multicolumn{2}{|c|}{ Mixed status } & \multicolumn{2}{|l|}{ No visa } \\
\hline & AME & se & AME & se & AME & se \\
\hline France & $-0.099^{+}$ & 0.058 & $-0.12 * *$ & 0.037 & $0.21 * *$ & 0.071 \\
\hline Spain & -0.13 & 0.085 & $-0.15^{*}$ & 0.077 & -0.058 & 0.048 \\
\hline Italy & $0.20 *$ & 0.10 & -0.015 & 0.052 & 0.060 & 0.042 \\
\hline
\end{tabular}

Source: MAFE-Senegal

Notes: ${ }^{+} p<0.10, * p<0.05, * * p<0.01,{ }^{* * *} p<0.001$

most likely to work upon arrival in Spain. The latter group is excluded from the model's risk set if they are already employed, meaning that the women with regular status making transitions to employment are likely to be reunified wives.

Other results may be indicative of autonomous migration strategies. The positive association between fully irregular status and transitions to employment in Italy means that migrants with fully irregular status in the first year-who are the most likely to be both in the labor force and unemployed - tend both to stay in this status and to find work. The effect of entry status is concentrated in France, where Senegalese women who enter without a visa have an employment-transition probability 21 percentage points higher than women who entered with a visa; these results may indicate an autonomous strategy where irregular entry is associated with eventual transitions to regular status and employment.

These results confirm the importance of including both entry status and timevarying legal status in models of employment for women (González-Ferrer 2011a) and suggest that women who enter through family-reunification mechanisms, who often have a mixed legal status that precludes work, are less likely to become employed than women who may circumvent such mechanisms.

Other predictors in the model are suggestive of a positive selection of employed Senegalese women: years of education, number of contacts at destination, and work experience in Senegal are all positively associated with becoming employed, suggesting that human and social capital play a role in this transition. In addition, planning to stay definitively in the destination is positively associated with becoming employed, while there is no association with having family either at destination or in Senegal.

\subsection{Discussion}

This chapter's main hypothesis is that the effect of legal status on Senegalese migrants' economic integration-as measured by first-year economic activity and employment dynamics - would vary systematically by gender as a result of gendered family reunification policies that produce different constraints and opportunities for men and women. The results for Senegalese women are largely consistent 
with a gendered migration system constructed by both legal channels open to women in the main contexts of reception and the constraints on female autonomy and mobility present in the gender norms of a patriarchal Senegalese context of exit. Across all three destination countries, women with legal-status configurations indicative of family reunification were more likely to be economically inactive during the year of arrival: women with fully regular status in France were less likely to work than women with mixed or irregular statues, while women with mixed status in Italy or Spain were less likely to work than women with fully regular statuses. These findings indicate the operation of administrative dependency (Boyd 1997; Kofman 1999; Lesselier 2008) and a concomitant decrease in the ability of women to enter the labor market. This is especially true in Spain and Italy, where legally mandated waiting periods on access to work permits erect a formal barrier to reunified spouses' participation.

Other variables associated with family reunification were also strongly predictive of first-year inactivity among women, including plans to stay definitively in the destination country, family financial participation in the trip, and having family motivations for the trip. The financial participation of women's families is overwhelmingly provided by reunifying husbands, and the association between this variable and women's inactivity suggests that men who can demonstrate the legally required financial means to bring a spouse can prevent reunified wives from working both by removing the economic necessity of women's work and potentially by making women economically dependent. Reunification and its associated economic dependency is thus a way to reproduce gendered hierarchies in a context where women's migration, even for reunification purposes, is strongly discouraged because of the fear of the loss of social control (Beauchemin et al. 2013).

Family reunification is often associated with dependency for women and at least an initial exclusion from labor-market participation, but research has also shown that reunified women may eventually work either as part of a family investment strategy (Duleep and Sanders 1993) or because of camouflaging of economic motivations in an "associational" move (Kanaiaupuni 2000). The results from this chapter support the contention that family reunification is not necessarily exclusive of eventual work. A discrete-time survival model showed that some of the legal-status configurations that were indicative of family reunification and first-year inactivity also predicted transitions into employment for women. This was directly evident for France, were women with fully regular status were more likely to make the transition to work than women with mixed or irregular status. In Spain, women with mixed status were less likely than women with regular status to make the transition; while reunified women have mixed status in Spain upon arrival, they are also able to access work authorization after a waiting period and those who do so are likely to find work. In these two countries, Kofman's (1999) observation that family reunification is liable to transform into another form of labor migration is accurate. Indeed, these findings call into question the common practice of relying on admissions categories as proxies for the motivations of individuals and also make a strong case for taking a longitudinal approach to the study of the labor-market integration of reunified migrants. 
Despite the predominance of family reunification as a legal migration channel for Senegalese women, this chapter's results also point to the existence of autonomous migration among Senegalese women with largely economic motives for their mobility. Senegalese women in France with mixed or irregular status during the year of arrival were likely not to be joining a partner and have economic motivations and were thus more likely to be employed during the year of arrival than women with fully regular status. These legal-status configurations indicate the predominance of semi-regular (in the case of students) and irregular work strategies among autonomous Senegalese women in France. In contrast, Senegalese women with fully regular status in Italy and Spain were more likely to work during the year of arrival than women with other statuses, indicating that these women are able to access legal channels of labor migration.

In contrast to the labor trajectories of Senegalese women, Senegalese men's economic integration showed little association with different configurations of legal status. Mixed status (lacking a work permit) was associated with inactivity, which is indicative of flows of students to Europe, especially France. Contrary to hypotheses, irregular status was not predictive of employment during the year of arrival, and regular status was not associated with transitions into unemployment. Senegalese men in Italy and Spain did exhibit significantly higher probabilities of employment during the year of arrival, however, lending support to the hypothesis that crossnational variation in labor markets would be associated with economic integration. It thus seems that Senegalese men are able to access employment in southern Europe regardless of their legal status, perhaps due to the extent of demand for low-skilled labor in these countries' robust informal economies, while Senegalese students in France are the only male migrants that face legal barriers to their employment.

These findings for Senegalese men are in keeping with literature that shows that migrants in such countries do not face an "ethnic penalty" in the probability of employment, but may face challenges in occupational mobility (Fullin and Reyneri 2011). Research with the MAFE data are indicative of the relatively low occupational attainment of Senegalese migrants in Europe (Obucina 2013), but additional research will be necessary to examine the link between legal status and occupational types. At the same time, Senegalese men in Spain face a higher risk of falling into unemployment than Senegalese men in France, indicating that employment, while perhaps easy to obtain, is somewhat precarious.

\subsection{Conclusion}

While the relationship between legal status and immigrant economic integration is a major concern of both policymakers and scholars, many studies of this link do not examine how the family context of migration influences both women's legal statuses and their participation in the labor market at destination. Legal status may matter more for women's economic integration because of the gendered immigration policies that produce them. While women migrants' experiences are growing 
more heterogeneous, many of them have entered destinations via the legal channel of family reunification. Their legal status is thus subject to their family situations.

Family-reunification legislation strongly structures entry channels for Senegalese women and produces legal statuses that either directly preclude their labor-market participation (as in Italy and Spain) or create other forms of economic and administrative dependency that may make them less likely to work even if they have the legal authorization to do so (as in France). Furthermore, motivations and preferences of reunified wives and their husbands also act to prevent women from working, thus acting through legal status to affect labor-market decisions of women.

This chapter found that Senegalese women with configurations of legal status indicative of family reunification were more likely than women with other legal statuses to be economically inactive upon arrival, while there is little association between Senegalese men's legal status and their participation. This finding held across destination countries despite the differing configurations of legal status granted to reunified spouses: while mixed status among women was associated with higher inactivity in Spain and Italy, so was fully regular status in France.

This is consonant with research that finds that reunified spouses tend to be less likely to be economically active (Kofman 1999). In the case of Spain and Italy these women face legal barriers to their participation as a result of waiting periods (Kofman 2004a). Women in France, however, do not face such barriers, meaning that their legal situation is also indicative of economic dependency (Lesselier 2008).

The results also show, however, that family reunification does not preclude labormarket participation, as many of the women with family-reunification profiles eventually transition into economic activity. This finding echoes the observation that family migration may transform into a form of labor migration (Kofman 1999). It also supports the view that women migrants have a diversity of motivations for their migration and may often strategically participate in an "associational" move for economic reasons (Kanaiaupuni 2000).

In contrast to Senegalese women, male migrants with fully irregular status (NRP_NWP) did not face any penalty in labor-market participation, employment, or the risk of transition to unemployment compared to migrants with fully regular status. The legal constraint of irregularity of legal status on economic activity for Senegalese migrants in Europe thus seems to be weak, supporting views that immigrants to countries with labor-market structures that favor low-skilled labor and informality reduce the immigrant "employment penalty" (Kogan 2006), perhaps at the risk of funneling them into "bad jobs" (Fullin and Reyneri 2011). 


\section{Appendix: Raw Coefficient Estimates for Models in this Chapter}

Multinomial logistic regression coefficients for first-year economic status, women and men

\begin{tabular}{|c|c|c|c|c|}
\hline \multirow[b]{3}{*}{ Predictor } & \multicolumn{2}{|l|}{ Women } & \multicolumn{2}{|l|}{ Men } \\
\hline & \multicolumn{2}{|c|}{ Outcome (ref: Unemployed) } & \multicolumn{2}{|c|}{ Outcome (ref.: Unemployed) } \\
\hline & Employed & Inactive & Employed & Inactive \\
\hline \multicolumn{5}{|c|}{ Legal status: (ref: fully regular) } \\
\hline $\begin{array}{l}\text { Fully } \\
\text { irregular (NRP_NWP) }\end{array}$ & $-0.31(-0.23)$ & $-1.73(-1.25)$ & $0.58(0.72)$ & $0.86(0.89)$ \\
\hline Mixed (RP_NWP) & $\begin{array}{l}14.03 * * * \\
(11.41)\end{array}$ & $\begin{array}{l}12.65 * * * \\
(10.48)\end{array}$ & $0.13(0.15)$ & $0.69(0.74)$ \\
\hline \multicolumn{5}{|l|}{ Destination (ref.: France) } \\
\hline Spain & $0.28(0.14)$ & $-1.92(-0.97)$ & $1.06(0.84)$ & $\begin{array}{l}-12.42 * * * \\
(-8.08)\end{array}$ \\
\hline Italy & $15.78 * * *(6.33)$ & $11.04 * * *(4.98)$ & $0.26(0.28)$ & $-4.24 *(-2.52)$ \\
\hline Fully irregular X Spain & $0.67(0.30)$ & $2.81(1.24)$ & $\begin{array}{l}-1.57 \\
(-1.12)\end{array}$ & $8.63 * * *(3.43)$ \\
\hline Fully irregulary X Italy & $\begin{array}{l}-16.88^{* * * *} \\
(-4.75)\end{array}$ & $\begin{array}{l}-12.66 * * * \\
(-3.75)\end{array}$ & $\begin{array}{l}-1.46 \\
(-1.35)\end{array}$ & $-0.63(-0.33)$ \\
\hline Mixed X Spain & $0.55(0.26)$ & $3.72^{+}(1.89)$ & $\begin{array}{l}-1.70 \\
(-0.92)\end{array}$ & $\begin{array}{l}10.05^{* * * *} \\
(3.40)\end{array}$ \\
\hline Mixed X Italy & $\begin{array}{l}-29.62 * * * \\
(-11.62)\end{array}$ & $\begin{array}{l}-24.72 * * * \\
(-10.90)\end{array}$ & $0.80(0.51)$ & $2.91(1.45)$ \\
\hline Entry status: no visa & $-2.76(-0.97)$ & $-2.48(-0.86)$ & $\begin{array}{l}-0.61 \\
(-0.82)\end{array}$ & $-0.85(-1.01)$ \\
\hline No visa $X$ Spain & $2.81(1.00)$ & $1.64(0.56)$ & $1.25(1.04)$ & $1.04(0.45)$ \\
\hline No visa $X$ Italy & $2.91(1.09)$ & $3.45(1.26)$ & $0.34(0.37)$ & $2.29(1.45)$ \\
\hline $\begin{array}{l}\text { Period of arrival: } \\
\text { post-1990 }\end{array}$ & $0.13(0.07)$ & $-0.07(-0.04)$ & $\begin{array}{l}-0.03 \\
(-0.05)\end{array}$ & $-0.58(-0.79)$ \\
\hline Age at start of current trip & $0.04(0.55)$ & $0.03(0.36)$ & $\begin{array}{l}-0.01 \\
(-0.17)\end{array}$ & $0.03(0.41)$ \\
\hline Years of education & $-0.08(-0.65)$ & $-0.07(-0.60)$ & $\begin{array}{l}-0.03 \\
(-0.76)\end{array}$ & $0.21 *(2.36)$ \\
\hline Ethnicity: Wolof & $0.91(0.85)$ & $1.10(1.02)$ & $0.74^{+}(1.87)$ & $0.48(0.86)$ \\
\hline Religion: Mouride & $0.58(0.55)$ & $0.50(0.47)$ & $0.50(1.12)$ & $0.19(0.32)$ \\
\hline $\begin{array}{l}\text { Number of contacts at } \\
\text { destination }\end{array}$ & $0.32^{+}(1.95)$ & $0.40 *(2.28)$ & $\begin{array}{l}-0.04 \\
(-0.38)\end{array}$ & $0.03(0.24)$ \\
\hline Number of trips & $2.37^{+}(1.88)$ & $2.70 *(2.12)$ & $0.07(0.45)$ & $-0.27(-0.67)$ \\
\hline $\begin{array}{l}\text { Does not speak lang. of } \\
\text { destination }\end{array}$ & $-1.48^{+}(-1.76)$ & $-0.90(-1.00)$ & $\begin{array}{l}-0.25 \\
(-0.53)\end{array}$ & $-0.15(-0.14)$ \\
\hline $\begin{array}{l}\text { Self-reported econ. status: } \\
\text { good }\end{array}$ & $2.93(1.53)$ & $1.93(0.98)$ & $\begin{array}{l}-0.07 \\
(-0.08)\end{array}$ & $0.42(0.43)$ \\
\hline Spouse or kid at dest. & $-0.41(-0.54)$ & $-0.34(-0.43)$ & $1.50^{+}(1.90)$ & $-0.71(-0.68)$ \\
\hline
\end{tabular}




\begin{tabular}{|c|c|c|c|c|}
\hline \multirow[b]{3}{*}{ Predictor } & \multicolumn{2}{|l|}{ Women } & \multicolumn{2}{|l|}{ Men } \\
\hline & \multicolumn{2}{|c|}{ Outcome (ref: Unemployed) } & \multicolumn{2}{|c|}{ Outcome (ref.: Unemployed) } \\
\hline & Employed & Inactive & Employed & Inactive \\
\hline Spouse or kid in Sn & $0.08(0.10)$ & $-1.26(-1.55)$ & $\begin{array}{l}-0.38 \\
(-0.91)\end{array}$ & $-0.43(-0.65)$ \\
\hline $\begin{array}{l}\text { Geographic origin: from } \\
\text { Dakar }\end{array}$ & $\begin{array}{l}-2.36^{* *} \\
(-2.64)\end{array}$ & $-2.32 *(-2.53)$ & \begin{tabular}{|l|}
-0.07 \\
$(-0.17)$
\end{tabular} & $1.15^{+}(1.76)$ \\
\hline $\begin{array}{l}\text { Father's ed.: < secondary } \\
\text { school }\end{array}$ & $1.27(1.18)$ & $1.00(0.94)$ & $0.07(0.15)$ & $-0.12(-0.22)$ \\
\hline Trip paid by family & $-0.08(-0.11)$ & $0.60(0.85)$ & \begin{tabular}{|l|}
-0.46 \\
$(-1.05)$
\end{tabular} & $\begin{array}{l}-2.15^{* *} \\
(-3.22) \\
\end{array}$ \\
\hline Plan to stay: definitive & $-2.04 *(-1.98)$ & $-1.06(-0.99)$ & $0.17(0.41)$ & $0.45(0.80)$ \\
\hline $\begin{array}{l}\text { Motivation for migration: } \\
\text { work }\end{array}$ & $0.58(0.80)$ & $-0.83(-1.09)$ & \begin{tabular}{|l|}
-0.05 \\
$(-0.10)$
\end{tabular} & $-1.44 *(-2.22)$ \\
\hline $\begin{array}{l}\text { At least one parent alive in } \\
\text { Senegal }\end{array}$ & $\begin{array}{l}-16.97 * * * \\
(-9.88)\end{array}$ & $\begin{array}{l}-16.12 * * * \\
(-8.94)\end{array}$ & $\begin{array}{l}-1.93^{+} \\
(-1.67)\end{array}$ & $-1.87(-1.19)$ \\
\hline Employed before trip & $2.35 *(2.11)$ & $2.81 *(2.42)$ & $0.74(1.29)$ & $0.58(0.59)$ \\
\hline Inactive before trip & $1.44(1.02)$ & $3.90 * *(2.72)$ & $1.14(1.20)$ & $3.62 * *(2.82)$ \\
\hline Years of work exp. (Sn) & $-0.12(-1.43)$ & $-0.13(-1.50)$ & $0.03(1.18)$ & $-0.04(-1.00)$ \\
\hline Constant & $16.81 * * *(6.26)$ & $15.44 * * *(5.50)$ & $3.19(1.57)$ & $-0.13(-0.05)$ \\
\hline Observations & \multicolumn{2}{|l|}{309} & \multicolumn{2}{|l|}{454} \\
\hline Pseudo R-squared & \multicolumn{2}{|l|}{0.417} & \multicolumn{2}{|l|}{0.455} \\
\hline AIC & \multicolumn{2}{|l|}{413.86} & \multicolumn{2}{|l|}{475.27} \\
\hline $\mathrm{BIC}$ & \multicolumn{2}{|l|}{607.99} & \multicolumn{2}{|l|}{738.83} \\
\hline Log likelihood & \multicolumn{2}{|l|}{-154.93} & \multicolumn{2}{|l|}{-173.64} \\
\hline Degrees of freedom & \multicolumn{2}{|l|}{45} & \multicolumn{2}{|l|}{62} \\
\hline
\end{tabular}

Source: MAFE-Senegal

Notes: $\mathrm{t}$ statistics in parentheses. ${ }^{+} p<0.10,{ }^{*} p<0.05,{ }^{* *} p<0.01,{ }^{* * *} p<0.001$. Multinomial logistic regression coefficients. Clustered standard errors

Discrete-time survival model for transitions into and out of employment for men and women, logistic regression coefficients

\begin{tabular}{l|l|l}
\hline \multirow{2}{*}{ Predictor } & Outcome & \\
\cline { 2 - 3 } & Women & Men \\
\cline { 2 - 3 } & Employment & Unemployment \\
\hline Legal status (ref.: fully regular) & \multicolumn{2}{l}{} \\
\hline Fully irregular (NRP_NWP) & $-1.17(-1.24)$ & $-0.32(-0.23)$ \\
\hline Mixed (RP_NWP) & $-1.47^{*}(-2.16)$ & $-1.53(-1.02)$ \\
\hline Destination (ref.: France) & $0.79(1.05)$ & $1.91(1.39)$ \\
\hline Spain & $-2.04(-1.43)$ & $1.25(0.87)$ \\
\hline Italy & $-0.23(-0.17)$ & $0.96(0.56)$ \\
\hline Fully irregular X Spain & $3.40 *(2.05)$ & $-2.32(-1.28)$ \\
\hline Fully irregular X Italy & $-0.44(-0.42)$ & $0.00()$. \\
\hline Mixed X Spain & $1.04(0.70)$ & $2.15(1.23)$ \\
\hline Mixed X Italy & &
\end{tabular}




\begin{tabular}{|c|c|c|}
\hline \multirow[b]{3}{*}{ Predictor } & \multicolumn{2}{|l|}{ Outcome } \\
\hline & Women & Men \\
\hline & Employment & Unemployment \\
\hline Entry status: no visa & $1.61 * *(3.27)$ & $-0.79(-1.02)$ \\
\hline No visa $X$ Spain & $-2.62 *(-2.42)$ & $2.23^{+}(1.89)$ \\
\hline No visa $X$ Italy & $-0.34(-0.34)$ & $0.65(0.62)$ \\
\hline Years in dest. & $0.14(1.01)$ & $-0.99(-1.18)$ \\
\hline Years in dest. squared & $-0.01 *(-2.47)$ & $-0.00(-0.73)$ \\
\hline Duration at risk & $0.10(0.80)$ & $0.06(0.18)$ \\
\hline Period of arrival: post-1990 & $1.50 * * *(3.33)$ & $1.20^{+}(1.84)$ \\
\hline Number of act. spells & $0.83 * * *(4.27)$ & $2.85 * * *(6.22)$ \\
\hline Age at start of current migration spell & $-0.02(-0.79)$ & $-0.08(-1.50)$ \\
\hline Years of education & $0.09 * *(2.61)$ & $-0.03(-0.43)$ \\
\hline Ethnicity: Wolof & $-0.46(-1.58)$ & $0.43(0.52)$ \\
\hline Religion: Mouride & $-0.36(-0.58)$ & $-1.02(-1.28)$ \\
\hline Years of ed. in dest. & $-0.05(-0.50)$ & $0.91(1.03)$ \\
\hline Self-reported econ. status: good & $-0.25(-0.33)$ & \\
\hline Number of contacts at destination & $0.12 *(2.03)$ & $-0.25^{+}(-1.83)$ \\
\hline Number of trips & $0.55(1.57)$ & $-0.02(-0.17)$ \\
\hline Does not speak language of destination & $-0.10(-0.17)$ & $-0.88(-1.29)$ \\
\hline Work exp. at dest. & - & $1.13(1.12)$ \\
\hline Unemployed & Ref. & - \\
\hline Employed & - & Ref. \\
\hline Inactive & $-0.96^{+}(-1.66)$ & $-0.40(-0.35)$ \\
\hline Manual occupation & - & $0.39(0.66)$ \\
\hline ISEI & - & $0.04 *(2.07)$ \\
\hline Spouse or kid at dest. & $0.08(0.17)$ & $0.25(0.50)$ \\
\hline Spouse or kid in Sn & $0.44(0.93)$ & $-0.61(-1.01)$ \\
\hline Geographic origin: from Dakar & $0.29(0.76)$ & $-0.11(-0.19)$ \\
\hline Father's ed.: < secondary school & $0.12(0.35)$ & $-0.57(-1.23)$ \\
\hline Trip paid by family & $0.02(0.04)$ & $-1.72 *(-2.58)$ \\
\hline Plan to stay: definitive & $0.71^{+}(1.86)$ & $0.46(0.88)$ \\
\hline Motive: work/better life & $0.53(1.44)$ & $-0.68(-1.33)$ \\
\hline Work exp. in Sn (years) & $0.07 * *(3.09)$ & \\
\hline Constant & $-6.89 * * *(-4.98)$ & $-8.86 * *(-3.28)$ \\
\hline Observations & 819 & 4010 \\
\hline Pseudo R-squared & 0.232 & 0.362 \\
\hline AIC & 502.15 & 332.42 \\
\hline $\mathrm{BIC}$ & 666.93 & 552.80 \\
\hline Log likelihood & -216.08 & -131.21 \\
\hline$\chi^{2}$ & 130.91 & 699.25 \\
\hline Degrees of freedom & 34 & 34 \\
\hline
\end{tabular}

Source: MAFE-Senegal

Notes: t statistics in parentheses. ${ }^{+} p<0.10,{ }^{*} p<0.05$, ${ }^{*} p<0.01$, ${ }^{* * *} p<0.001$. Logistic regression coefficients displayed. Clustered standard errors 


\section{References}

Amuedo-Dorantes, C., Malo, M. A., \& Muñoz-Bullón, F. (2013). New evidence on the impact of legal status on immigrant labor market performance: The Spanish case. LABOUR, 27(1), 93-113.

Baizan, P., Beauchemin, C., \& Ferrer, A. G. (2011). A reassessment of family reunification in Europe: The case of Senegalese couples (Vol. 16). Paris: INED.

Barou, J. (1993). Les immigrations Africaines En France: Des «navigateurs» Au «regroupement Familial». Revue Française Des Affaires Sociales, 1, 193-205.

Beauchemin, C., Caarls, K., \& Mazzucato, V. (2013). Senegalese migrants between here and there: An overview of family patterns. MAFE Working Papers (MAFE Working Paper 33). Paris: INED.

Bernardi, F., Garrido, L., \& Miyar, M. (2011). The recent fast upsurge of immigrants in Spain and their employment patterns and occupational attainment. International Migration, 49(1), 148-187.

Borjas, G. J. (1985). Assimilation, changes in Cohort quality, and the earnings of immigrants. Journal of Labor Economics, 3(4), 463-489.

Borjas, G. J. (1995). Assimilation and changes in Cohort quality revisited: What happened to immigrant earnings in the 1980s? Journal of Labor Economics, 13(2), 201-245.

Boyd, M. (1989). Family and personal networks in international migration: Recent developments and new agendas. International Migration Review, 23(3), 638-670.

Boyd, M. (1997). Migration policy, female dependency, and family membership: Canada and Germany. In P. M. Evans \& G. R. Wekerle (Eds.), Women and the Canadian welfare state: Challenges and change (pp. 142-169). Toronto: University of Toronto Press.

Bradatan, C. E., \& Sandu, D. (2012). Before crisis: Gender and economic outcomes of the two largest immigrant communities in Spain. International Migration Review, 46(1), 221-243.

Castagnone, E., Sakho, P., Nazio, T., Schoumaker, B., \& Rakotonarivo, N. (2013). African migrants at work. Patterns of labour market integration in Europe, transnational economic participation and economic re-integration of migrants in origin countries. The case of Senegal. MAFE working papers (MAFE Working Paper 29). Paris: INED.

Cerrutti, M., \& Massey, D. S. (2001). On the auspices of female migration from Mexico to the United States. Demography, 38(2), 187-200.

Chiswick, B. R. (1978). The effect of Americanization on the earnings of foreign-born men. Journal of Political Economy, 86(5), 897-921.

Chort, I., Gubert, F., \& Senne, J.-N. (2012). Migrant networks as a basis for social control: Remittance incentives among Senegalese in France and Italy. Regional Science and Urban Economics, 42(5), 858-874.

Constant, A., \& Zimmermann, K. F. (2005). Immigrant performance and selective immigration policy: A European perspective. National Institute Economic Review, 194(1), 94-105.

di Friedberg, O. S. (1993). L'immigration Africaine En Italie: Le Cas Sénégalais. Etudes Internationales, 24(1), 125-140.

Donato, K. M., \& Massey, D. S. (1993). Effect of the immigration reform and control act on the wages of Mexican migrants. Social Science Quarterly (University of Texas Press), 74(3), 523-541.

Donato, K. M., Wakabayashi, C., Hakimzadeh, S., \& Armenta, A. (2008). Shifts in the employment conditions of Mexican migrant men and women The effect of U.S. immigration policy. Work and Occupations, 35(4), 462-495.

Duleep, H. O., \& Sanders, S. (1993). The decision to work by married immigrant women. Industrial and Labor Relations Review, 46(4), 677-690.

Fullin, G., \& Reyneri, E. (2011). Low unemployment and bad jobs for new immigrants in Italy. International Migration, 49(1), 118-147.

González-Enríquez, C. (2009). Spain, the cheap model: Irregularity and regularisation as immigration management policies. European Journal of Migration and Law, 11, 139. 
González Ferrer, A. (2006). Family and labor strategies in migration: Family reunification, marital choices and labor participation of immigrants in the Host country. Doctoral thesis, Instituto Juan March de Estudios e Investigaciones, Centro de Estudios Avanzados en Ciencias Sociales, Universidad Autónoma de Madrid, Madrid.

González-Ferrer, A. (2011a). Explaining the labour performance of immigrant women in Spain: The interplay between family, migration and legal trajectories. International Journal of Comparative Sociology, 52(1-2), 63-78.

González-Ferrer, A. (2011b). The reunification of the spouse among recent immigrants in Spain. Links with undocumented migration and the labour market. In A. Kraler, E. Kofman, M. Kohli, \& C. Schmoll (Eds.), Gender, Generations and the family in international migration (pp. 143166). Amsterdam: Amsterdam University Press.

Hall, M., Greenman, E., \& Farkas, G. (2010). Legal status and wage disparities for Mexican immigrants. Social Forces, 89(2), 491-513.

Heath, A., \& Ridge, J. (1983). Social mobility of ethnic minorities. Journal of Biosocial Science, 15.(Supplement S8, 169-184.

Huddleston, T., Dag Tjaden, J., \& Callier, L. (2012). Immigrant citizens survey: How immigrants experience integration in 15 European cities. Brussels: King Baudouin Foundation and Migration Policy Group.

Kaag, M. (2008). Mouride transnational livelihoods at the margins of a European society: The case of residence Prealpino, Brescia, Italy. Journal of Ethnic \& Migration Studies, 34(2), 271-285.

Kanaiaupuni, S. M. (2000). Reframing the migration question: An analysis of men, women, and gender in Mexico. Social Forces, 78(4), 1311-1347.

Kofman, E. (1999). Female 'birds of passage' a decade later: Gender and immigration in the European union. International Migration Review, 33(2), 269-299.

Kofman, E. (2004a). Family-related migration: A critial review of European studies. Journal of Ethnic and Migration Studies, 30(2), 243-262.

Kofman, E. (2004b). Gendered global migrations. International Feminist Journal of Politics, 6(4), 643-665.

Kogan, I. (2006). Labor markets and economic incorporation among recent immigrants in Europe. Social Forces, 85(2), 697-721.

Kossoudji, S. A., \& Cobb-Clark, D. A. (2000). IRCA's impact on the occupational concentration and mobility of newly-legalized Mexican men. Journal of Population Economics, 13(1), 81-98.

Kossoudji, S. A., \& Cobb-Clark, D. A. (2002). Coming out of the shadows: Learning about legal status and wages from the legalized population. Journal of Labor Economics, 20(3), 598-628.

Lesselier, C. (2008). Politiques d'immigration en France : appréhender la dimension de genre. Les cahiers du CEDREF. Centre d'enseignement, d'études et de recherches pour les études féministes, 16, 189-208.

Mahler, S. J., \& Pessar, P. R. (2006). Gender matters: Ethnographers bring gender from the periphery toward the core of migration studies. International Migration Review, 40(1), 27-63.

Massey, D. S. (1987). Do undocumented migrants earn lower wages than legal immigrants? New evidence from Mexico. International Migration Review, 21(2), 236-274.

Massey, D. S., Durand, J., \& Malone, N. J. (2002). Beyond smoke and mirrors: Mexican immigration in an era of economic integration. New York: Russell Sage Foundation.

Mezger, C., \& González-Ferrer, A. (2013). The impol database: A new tool to measure immigration policies in France, Italy and Spain since the 1960s (Vol. 34). Paris: INED.

Mincer, J. (1978). Family migration decisions. Journal of Political Economy, 86(5), 749-773.

Obucina, O. (2013). Occupational trajectories and occupational cost among Senegalese immigrants in Europe. Demographic Research, 28, 547-580.

Pascual de Sans, Angels, J. C., \& Solana, M. S. (2000). Recent immigration to catalonia: Economic character and responses. In R. King, G. Lazaridis, \& C. Tsardanidis (Eds.), Eldorado or fortress?: Migration in Southern Europe (pp. 104-124). New York: St. Martin's Press. 
Phillips, J. A., \& Massey, D. S. (1999). The new labor market: Immigrants and wages after IRCA. Demography, 36(2), 233-246.

Piore, M. J. (1979). Birds of passage: Migrant labor and industrial societies. Cambridge: Cambridge University Press.

Portes, A. (1978). Introduction: Toward a structural analysis of illegal (undocumented) immigration. International Migration Review, 12(4), 469-484.

Raghuram, P. (2004). The difference that skills make: Gender, family migration strategies and regulated labour markets. Journal of Ethnic and Migration Studies, 30(2), 303-321.

Reyneri, E., \& Fullin, G. (2011). Labour market penalties of new immigrants in new and old receiving west European countries. International Migration, 49(1), 31-57.

Riccio, B. (2001). From 'ethnic group' to 'transnational community'? Senegalese migrants' ambivalent experiences and multiple trajectories. Journal of Ethnic and Migration Studies, 27, 583-599.

Riccio, B. (2008). West African transnationalisms compared: Ghanaians and Senegalese in Italy. Journal of Ethnic \& Migration Studies, 34(2), 217-234.

Rivera-Batiz, F. L. (1999). Undocumented workers in the labor market: An analysis of the earnings of legal and illegal Mexican immigrants in the United States. Journal of Population Economics, 12(1), 91-116.

Sandell, S. H. (1977). Women and the economics of family migration. The Review of Economics and Statistics, 59(4), 406-414.

Tall, S. M. (2008b). Les Émigrés Sénégalais En Italie. Transferts Financiers et Potentiel de Développement de l'habitat Au Sénégal. In M.-C. Diop (Ed.), Le Sénégal Des Migrations: Mobilités, Identités Et Sociétés, Hommes et sociétés (pp. 37-67). Paris: Karthala.

Timera, M. (1997). L'immigration Africaine En France: Regards Des Autres et Repli Sur Soi: La France et Les Migrants Africains= The African immigration in France: The withdrawal of the other: France and the African migrants. Politique Africaine, 67, 41-47.

Toma, S. (2012). Ties that bind? Networks and gender in international migration. D.Phil. thesis, Nuffield College, University of Oxford, Oxford.

Open Access This chapter is licensed under the terms of the Creative Commons Attribution 4.0 International License (http://creativecommons.org/licenses/by/4.0/), which permits use, sharing, adaptation, distribution and reproduction in any medium or format, as long as you give appropriate credit to the original author(s) and the source, provide a link to the Creative Commons licence and indicate if changes were made.

The images or other third party material in this chapter are included in the chapter's Creative Commons licence, unless indicated otherwise in a credit line to the material. If material is not included in the chapter's Creative Commons licence and your intended use is not permitted by statutory regulation or exceeds the permitted use, you will need to obtain permission directly from the copyright holder.

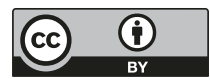

